\title{
Rock-Eval 6 Technology: Performances and Developments
}

\author{
F. Behar ${ }^{1}$, V. Beaumont ${ }^{1}$ and H.L. De B. Penteado² \\ 1 Institut français du pétrole, Division géologie-géochimie, 1 et 4, avenue de Bois-Préau, 92852 Rueil-Malmaison Cedex - France \\ 2 Cenpes, Petrobras Research Center, Citade Universitaria, Rio de Janeiro - Brazil \\ e-mail: francoise.behar@ifp.fr - valerie.beaumont@ifp.fr - hpenteado@cenpes.petrobras.com.br
}

\begin{abstract}
Résumé - Technologie Rock-Eval 6 : performances et développements - Le Rock-Eval 6 est la dernière version de la ligne de produits Rock-Eval, commercialisée par Vinci Technologies depuis 1996. Le présent article décrit la méthodologie développée à l'IFP pour l'obtention de données fiables et atteste la qualité des paramètres géochimiques acquis par le Rock-Eval 6. Les données ont été obtenues sur 147 roches mères provenant de bassins sédimentaires variés et présentant des matières organiques des différents types à différents stades de maturité.
\end{abstract}

Des corrélations intrinsèques, sur deux appareils Rock-Eval 6 différents, ont été réalisées et les données obtenues démontrent une excellente uniformité pour l'ensemble du jeu de paramètres Rock-Eval.

Le recouvrement complet du carbone total (CT) par le Rock-Eval 6 a été confirmé par comparaison avec l'analyse élémentaire.

Afin de vérifier la répartition du carbone (minéral et organique) réalisée par le Rock-Eval 6, des mesures du carbone minéral (MinC) et du carbone organique total (COT) ont été effectuées par des techniques alternatives.

Le carbone organique total mesuré par le Rock-Eval 6 a été comparé à ceux obtenus par l'appareil Leco pour les roches brutes, par l'analyse élémentaire pour les kérogènes, et par le calcul à partir du bilan de masse effectué après destruction de la matrice minérale et la concentration en carbone mesurée par analyse élémentaire sur les kérogènes ainsi obtenus pour les roches brutes.

Une bonne corrélation est obtenue pour toute la gamme de concentration (0-90 \% en poids) lorsque l'on compare le Rock-Eval 6 et l'analyse élémentaire. La comparaison avec le Leco présente de plus importantes déviations, bien que le coefficient de corrélation soit satisfaisant.

Les kérogènes recouvrés ont été soumis à l'analyse élémentaire et les quantités de carbone mesurées ont été comparées à celles obtenues par analyse Rock-Eval 6.

Pour un sous-ensemble de kérogènes, des pyrolyses préparatives ont été réalisées afin de confirmer la valeur de $83 \%$ en poids pour le carbone organique contenu dans le pic $S 2$ pour toutes les roches, quel que soit le type de la matière organique, et de vérifier la valeur absolue du pic $S 2$.

Le carbone minéral mesuré par Rock-Eval 6 a été comparé à ceux obtenus par détermination de la perte de poids après traitement $\mathrm{HCl}$, par la technique d'acidimétrie, et par le calcul à partir du $\mathrm{TC}$, le bilan de masse obtenu lors de la préparation du kérogène et la concentration en carbone du kérogène. Une bonne corrélation est obtenue pour toute la gamme de concentration (0-12\% en poids) lors de la comparaison avec l'analyse élémentaire. De plus importantes déviations et un coefficient de corrélation satisfaisant sont obtenus pour la comparaison avec l'acidimétrie. La comparaison avec la détermination de perte de poids est médiocre. 
En conclusion, une excellente fiabilité a été démontrée pour le COT et le MinC mesurés par Rock-Eval 6. En conséquence, il est désormais possible d'obtenir un bilan du carbone minéral et organique contenu dans une roche par une mesure unique. Des recommandations sont proposées concernant les échantillons de référence et les méthodes analytiques sélectionnées pour calibrer le Rock-Eval 6 sur une large gamme de carbone organique et minéral.

L'uniformité entre les valeurs de $S 2$ et de Tmax mesurées par le Rock-Eval 2 d'une part, et le Rock-Eval 6 d'autre part, pour les roches brutes de type I et de type II a également été vérifiée. Une bonne corrélation a été obtenue pour le $S 2$, bien que les valeurs mesurées par le Rock-Eval 2 soient d'une manière générale légèrement supérieures. Il a été démontré que ce point était lié au gaz vecteur (azote et hélium) en réalisant des analyses sous Rock-Eval 6 avec l'hélium comme gaz vecteur. La différence est de 5 à $10 \%$ en poids relatif pour la plupart des échantillons étudiés. La corrélation des Tmax présente une grande dispersion et en tendance générale, les valeurs de Tmax obtenues par Rock-Eval 6 sont supérieures à celles obtenues par Rock-Eval 2, la différence augmentant avec la valeur du Tmax. Ceci est dû au fait que le thermocouple régulant le four du Rock-Eval 2 est placé dans la paroi du four de pyrolyse : en conséquence, la détermination du Tmax est dépendante du réglage et du calibrage de l'appareil. Une attention spéciale a été portée au contrôle de la température dans le Rock-Eval 6, où le thermocouple est directement placé sous la nacelle contenant l'échantillon, aboutissant à des mesures plus fiables.

Mots-clés : Rock-Eval, pyrolyse, COT, carbone minéral, potentiel pétrolier, caractérisation des kérogènes.

Abstract - Rock-Eval 6 Technology: Performances and Developments - The Rock-Eval 6 apparatus is the latest version of the Rock-Eval product line, commercialized since 1996 by Vinci Technologies. The present work describes the methodology developed at IFP for reliable data acquisition and endorses the quality of geochemical parameters acquired with Rock-Eval 6. Data were obtained on 147 source rocks from various sedimentary basins, of different organic matter types and maturity stages.

Intrinsic correlations for two different Rock-Eval 6 apparatus were performed and the obtained data set shows an excellent consistency and good reproducibility conditions for the whole set of Rock-Eval parameters.

Complete recovery of total carbon (TC) by Rock-Eval 6 was confirmed by comparison with elemental analysis.

In order to check the carbon partition (mineral vs. organic) determined by Rock-Eval 6, measurements of mineral carbon (MinC) and total organic carbon (TOC) were performed by alternative techniques.

TOC measured by Rock-Eval 6 was compared to that obtained either by: the Leco apparatus for bulk rocks; elemental analysis for kerogens; and calculation from the mass balance determined after destruction of mineral matrix and the carbon concentration determined by elemental analysis on recovered kerogens for bulk rocks. The results display a good correlation for the whole concentration range (0-90 wt\% TOC), when comparing elemental analyses and Rock-Eval 6 for source rocks and kerogens. However, comparison of Rock-Eval 6 with Leco data leads to larger deviations while correlation factors are still good.

For a subset of kerogen samples, preparative pyrolysis was performed in order to confirm the value of 83 wt\% for the organic carbon of the total S2 peak for any rock with any organic type and to check the absolute value of the S2 peak by gas chromatography analysis of pyrolysis by-product.

MinC measured with Rock-Eval 6 was compared to that determined by: weight loss after HCl treatment; the acidimetry technique; and calculation after TC, mass balance from kerogen isolation and organic carbon measurement on kerogen by elemental analysis. The results display a good correlation for the whole concentration range (0-12 wt\% MinC), when comparing elemental analyses and Rock-Eval 6. However, comparison of Rock-Eval 6 with acidimetry data leads to larger deviations while correlation factors are still good while comparison with weight loss is poor.

As a whole an excellent reliability of TOC and MinC obtained by Rock-Eval 6 was demonstrated, and consequently, it is now possible to get at once the total organic and mineral carbon mass balance for a given rock. Recommendations are proposed regarding the standard samples and analytical methods selected for calibrating the Rock-Eval 6 over a large mineral and organic carbon range.

Consistency between S2 and Tmax measured by Rock-Eval 2 and Rock-Eval 6 for Types I and II bulk rocks was also checked. A good correlation was obtained for S2, even though S2 values are slightly 
higher when measured with Rock-Eval 2. It was demonstrated that this is due to carrier gas (nitrogen vs. helium) by running measurements with a Rock-Eval 6 under helium, the difference ranging from 5 to 10 relative wt $\%$ for most studied samples. For Tmax correlation, data are much more scattered and as a general trend Tmax obtained by Rock-Eval 6 are higher than Tmax obtained by Rock-Eval 2 and the difference increases with Tmax: this is due to the fact that the probe measuring the temperature in the Rock-Eval 2 is located in the oven wall, consequently Tmax determination is highly dependent on the setup and calibration of the apparatus. A special attention was given for temperature measurement in the Rock-Eval 6, where the probe is in contact with the crucible containing the sample, leading to much more reliable data.

Keywords: Rock-Eval, pyrolysis, TOC, mineral carbon, oil potential, kerogen typing.

\section{INTRODUCTION}

The Rock-Eval pyrolysis method has been extensively used for oil and gas exploration in sedimentary basins over the world. This technique uses temperature programmed heating of a small amount of rock (70 mg) or coal (30-50 mg) in an inert atmosphere (helium or nitrogen) in order to determine the quantity of free hydrocarbons present in the sample ( $S 1$ peak) and of those that can be potentially released after maturation ( $S 2$ peak). The Tmax value is a standardized parameter, calculated from the temperature at which the $S 2$ peak reaches its maximum: this parameter is used as a maturity parameter for fossil organic matter. These parameters describe the quality of organic matter in the rock sample for exploration purpose. For a more complete diagnosis, total organic content (TOC) has to be determined together with the mineral carbon content (MinC). The latest version of the Rock-Eval product line, i.e. the Rock-Eval 6, described by Lafargue et al. (1998), enables the determination of Rock-Eval parameters plus TOC and MinC as it is equipped with an oven for combustion of the rock residue after pyrolysis, and an infra-red cell ensuring the continuous monitoring of $\mathrm{CO}$ and $\mathrm{CO}_{2}$ released during both pyrolysis and combustion. By studying the specific thermal decomposition of the carbonates during pyrolysis (Lafargue et al., 1998), it is now possible to subtract from the total carbon curves during the pyrolysis and combustion stages, the contribution of the mineral carbon and to get a precise organic carbon profile. An important part of the present paper is dedicated to demonstrate the measurement accuracy for both organic and mineral carbon for a large concentration range (from less than 1 to $90 \mathrm{wt} \%$ for the organic carbon and less than 1 to $14 \mathrm{wt} \%$ for the mineral carbon) by intrinsic correlation between two Rock-Eval 6 apparatus and comparison with classical techniques (Leco for TOC; weight loss and acidimetry for MinC).

\section{Rock-Eval 6 parameters}

\begin{tabular}{|c|}
\multicolumn{1}{c|}{$\begin{array}{c}\text { otal carbon } \\
\text { (TC) }\end{array}$} \\
\hline Source rocks + coals \\
\hline $\begin{array}{l}\text { Elemental analysis }(\mathrm{EA}) \\
\text { combustion at } 1300^{\circ} \mathrm{C} \\
\mathrm{TC}=\left[\Sigma\left(\mathrm{CO}+\mathrm{CO}_{2}\right)\right]_{\mathrm{EA}}\end{array}$ \\
\hline
\end{tabular}

otal carbon

Total organic

(1)

\begin{tabular}{|l|}
\hline $\begin{array}{c}\text { i.o.m. + coals } \\
\text { decarbonated source rocks }\end{array}$ \\
\hline Elemental analysis $(\mathrm{EA})$ \\
combustion at $1000^{\circ} \mathrm{C}$ \\
$\mathrm{TOC}=\left[\Sigma\left(\mathrm{CO}+\mathrm{CO}_{2}\right)\right]_{\mathrm{EA}}$ \\
\hline
\end{tabular}

(2)

\begin{tabular}{|c|}
\hline \multicolumn{1}{|c|}{ Source rocks } \\
\hline Mineral destruction EA \\
on recovered i.o.m. $\left(\mathrm{C}_{\text {i.o.m. }}\right)$ \\
TOC $=\left[M 1 \times \mathrm{C}_{\text {i.o.m. }}\right] / M 2$ \\
$M 1=$ i.o.m. mass \\
$M 2=$ initial SR mass \\
\hline (3) \\
\hline Decarbonated source rocks \\
\hline Leco technique \\
\hline
\end{tabular}

Mineral carbon (MinC)

\begin{tabular}{|l|}
\hline Source rocks \\
\hline $\begin{array}{l}\text { 1) Acidimetry } \\
\text { 2) Weight loss after } \\
\text { decarbonation }\end{array}$ \\
\hline
\end{tabular}

Carbon content of the $S 2$ peak

\begin{tabular}{|l|l|}
\hline \multicolumn{1}{|c|}{ i.o.m. + coals } & Source rocks \\
\hline $\begin{array}{l}\text { Preparative pyrolysis } \\
\text { EA on the recovered } \\
\text { pyrolysate } \\
C_{S 2}=C_{\text {gas }}+C_{\text {liquid }}\end{array}$ & Rock-Eval 2 \\
\hline
\end{tabular}

Tmax, S2

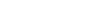


As indicated in Lafargue et al. (1998), the pyrolysis furnace of the Rock-Eval 6 is able to reach a final temperature of $800^{\circ} \mathrm{C}$ instead of $600^{\circ} \mathrm{C}$ and the carrier gas helium in Rock-Eval 2 was replaced by nitrogen in RockEval 6. Using the same set of rock samples as those used for carbon measurements, excluding coals, Rock-Eval parameters ( $S 2$ and Tmax) obtained with Rock-Eval 6 are compared with those obtained with the Rock-Eval 2.

The main objective of this work is to add a metrological dimension to the previous paper presented by Lafargue et al. (1998) with:

- recalling of the Rock-Eval 6 method developed at IFP for bulk rocks and coals and isolated organic matter (i.o.m.) and description of the Rock-Eval 6 parameters and derived calculations;

- evaluation of the reproducibility of the Rock-Eval 6 parameters;

- verification of the organic carbon in the $S 2$ peak;

- comparison and validation of the Rock-Eval 6 parameters with those obtained by other techniques: the total carbon content (TC) with elemental analysis; the organic total content (TOC) with elemental analysis and Leco; the MinC with elemental analysis, weight loss estimation after decarbonation and acidimetry technique; and the $S 2$ and Tmax with Rock-Eval 2 apparatus.

The strategy and analytical methods involved in this work are summarized in Figure 1.

\section{SAMPLES}

We have selected in the IFP rock collection 147 source rocks from various basins, representative of the three origin types: their main characteristics are given in Table 1.

TABLE 1

Geographic and kerogen type distribution of the 147 source rocks selected for the study

\begin{tabular}{l|c|c|c|c}
\hline \multirow{2}{*}{ Country } & \multicolumn{2}{|c|}{ Number of samples } & \multirow{2}{*}{ Type } & $\begin{array}{c}\text { Tmax range } \\
\left({ }^{\circ} \mathbf{C}\right)\end{array}$ \\
\cline { 2 - 3 } & Bulk rocks & i.o.m. & & I \\
\hline Brazil & 21 & 5 & $413-440$ \\
Brazil & 27 & 26 & I & $436-448$ \\
Brazil & 22 & 20 & I & $426-449$ \\
USA & 11 & 12 & I & $427-468$ \\
West Africa & 6 & 5 & I & $437-449$ \\
Canada & 11 & 11 & II & $421-489$ \\
Germany & 6 & 6 & II & $433-463$ \\
Middle East & 8 & 8 & II & $414-444$ \\
West Africa & 8 & 8 & II & $424-435$ \\
Thailand & 14 & 13 & III coal & $424-474$ \\
USA & 13 & 13 & III coal & $418-475$ \\
\hline
\end{tabular}

The rock selection was based on the availability of both bulk rocks and corresponding kerogens, the variability of the organic carbon content, the carbonate content and the organic matter type and its maturity stage.

Data given in Table 1 show that the samples which fulfill our conditions are biased to Type I organic matter.

\section{EXPERIMENTAL}

\subsection{Rock-Eval 6 IFP Methods}

A single method was developed in IFP in order to run any type of bulk source rock: it is called Basic Method. Another method called Pure Organic Matter Method was developed for the i.o.m. and coal samples. In this paragraph are given: a detailed description of the Rock-Eval 6 apparatus and of the calculated parameters; the IFP method for source rock analysis; the IFP method for organic matter analysis; and the Rock-Eval 2 technique.

\subsubsection{Description of the Rock-Eval 6 Apparatus}

The Rock-Eval method consists in estimating the petroleum potential of sedimentary rocks by heating samples in an open pyrolysis system under non-isothermal conditions. The released hydrocarbons are monitored by a flame ionization detector (FID), forming the so-called peaks S1 (thermovaporized free hydrocarbons) and $S 2$ (pyrolysis products from cracking of organic matter). The method is completed by combustion (oxidation) of the residual rock recovered after pyrolysis up to $850^{\circ} \mathrm{C}$, under artificial air $\left(\mathrm{N}_{2} / \mathrm{O}_{2}\right.$; 80/20). During pyrolysis and combustion, released $\mathrm{CO}$ and $\mathrm{CO}_{2}$ are monitored on line by means of an infra-red cell. This complementary data acquisition enables determination of the organic and mineral carbon content of samples, labeled TOC and $\mathrm{MinC}$ respectively.

The innovations of the Rock-Eval 6 are:

- micro-ovens heating up to $800^{\circ} \mathrm{C}$ for pyrolysis and $850^{\circ} \mathrm{C}$ for combustion with probes in contact with the sample, allowing a better temperature control;

- infra-red cells for on-line continuous recording of $\mathrm{CO}_{2}$ and $\mathrm{CO}$ production during pyrolysis and oxidation;

- an automatic sequenced sampler with a capacity of 48 samples, which allows running 24 hours a day, 7 days a week.

Three of the four commercialized versions are presented in Figure 2. The "classic S3" version is not equipped with the additional oven for combustion of the pyrolysis residue. The other two versions are equipped with two ovens (pyrolysis and combustion): the same parameters are measured for both apparatus, but for the "Turbo" apparatus, the pyrolysis (25 min including cooling) and combustion (38 min) steps of two successive samples are run in parallel, thus, the 


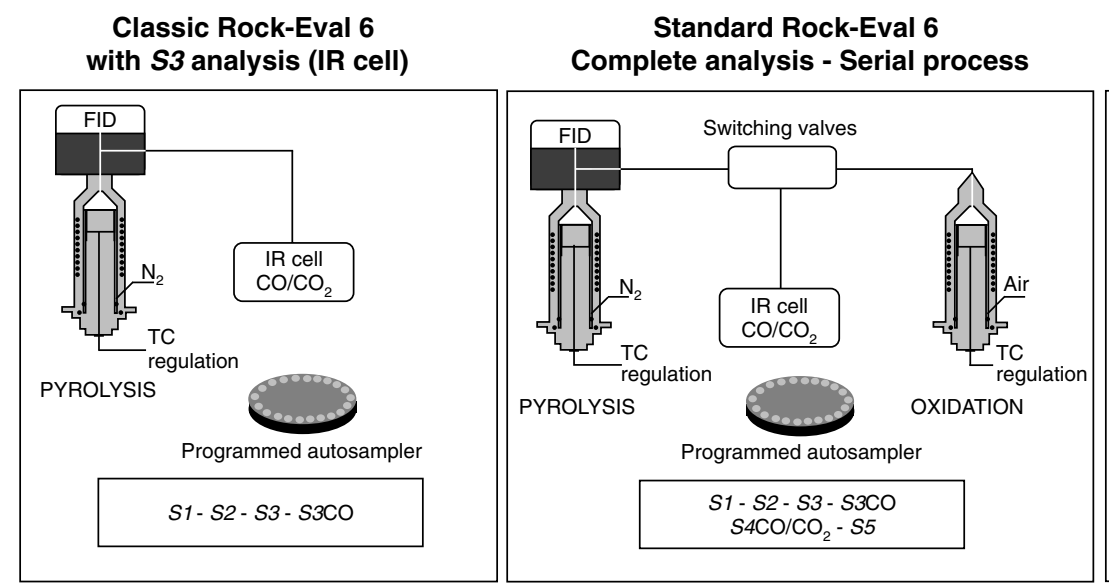

Turbo Rock-Eval 6 Complete analysis - Parallel process

Figure 2

Presentation of the different Rock-Eval 6 versions commercialized by Vinci Technologies.

acquisition time is highly reduced. In fact, except for the first and the last samples of the same series, pyrolysis and combustion steps are run together. Consequently, the first and the last analyses last $63 \mathrm{~min}$ whereas the other lasts only 38 min.

Typical sample amount ranges from 50 to $70 \mathrm{mg}$ for bulk rocks, from 10 to $30 \mathrm{mg}$ for coals and from 5 to $15 \mathrm{mg}$ for i.o.m. However, for high petroleum potential kerogens such as those of Type I, the sample amount can be reduced to 1-2 mg.

The initial weight has to be measured with a precision of $0.5 \mathrm{mg}$ for bulk rocks and of $0.02 \mathrm{mg}$ for kerogen and coals in order to obtain reliable Rock-Eval parameters (i.e. $S 2 \pm$ $0.5 \mathrm{mg} / \mathrm{g}$ rock, TOC and MinC $\pm 0.1 \mathrm{wt} \%$ ).

Two different methods were used for running the bulk source rocks on the one hand and the i.o.m. and/or coals on the other. They are described in Figures $3 a$ and $3 b$.

\subsubsection{IFP Basic Method for Source Rocks}

The method used for running bulk source rocks is called Basic Method and the corresponding pyrolysis and combustion conditions as well as integration conditions for the determination of the acquisition parameters are summarized in Figure 3a.

Acquisition and calculated parameters are given in Tables $2 \mathrm{a}$ and $2 \mathrm{~b}$ respectively.

During the pyrolysis step, the recorded FID signal that corresponds to the petroleum potential is divided into two surfaces: $S 1$ and $S 2$, which are expressed in $\mathrm{mg} \mathrm{HC/g}$ of initial rock. $S 1$ corresponds to the quantity of hydrocarbons released during the isothermal temperature step at $300^{\circ} \mathrm{C}$ and represents the thermovaporized free hydrocarbons contained in the rock. $S 2$ corresponds to the quantity of hydrocarbons released between $300^{\circ}$ and $650^{\circ} \mathrm{C}$ and represents the hydrocarbons resulting from the cracking of sedimentary organic matter. Assuming an average value of $83 \mathrm{wt} \%$ for the carbon content of the $S 2$ surface whatever the organic matter type (Espitalié et al., 1985a, 1985b, 1985c), it is possible to calculate the corresponding absolute organic carbon content of released hydrocarbons. The same calculation is done for the absolute organic carbon content of the $S 1$ surface.

The total $\mathrm{CO}$ signal obtained during pyrolysis is split into two surfaces: the first one $(\mathrm{S} 3 \mathrm{CO})$ integrates the $\mathrm{CO}$ released from the beginning of measurements $\left(t=0, T=300^{\circ} \mathrm{C}\right)$ up to the temperature where a minimum of $\mathrm{CO}$ production is observed (between $450^{\circ}$ and $600^{\circ} \mathrm{C}$ ). When no minimum is detected, the integration limit is fixed at $550^{\circ} \mathrm{C}$ as default parameter. The second surface $\left(S 3^{\prime} \mathrm{CO}\right)$ starts at the upper limit defined for the previous surface and ends up at the end of the measurement. The $S 3 \mathrm{CO}$ surface corresponds to the release of functions linked to organic matter and this signal will be integrated into the calculation of TOC. The $S 3$ ' $\mathrm{CO}$ is due to the reactivity of $\mathrm{CO}_{2}$ released during the thermal decomposition of carbonates on the organic matter according to the so-called Boudouard reactions, producing two $\mathrm{CO}$ molecules, one with a carbon of organic origin integrated into the calculation of TOC, and the other one with a carbon of mineral origin integrated into the calculation of MinC.

During the oxidation stage, only one CO signal is integrated from beginning to end of the measurement and labeled S4CO. All the carbon contained in this $\mathrm{CO}$ is of organic origin.

In the same way, the $\mathrm{CO}_{2}$ yield during the pyrolysis stage is split into $S 3$, which corresponds to $\mathrm{CO}_{2}$ released at the same time as the $S 1$ peak added to that obtained between $300^{\circ}$ and $400^{\circ} \mathrm{C}$ with an organic origin, and $S 3$ ', which is the $\mathrm{CO}_{2}$ recorded between $400^{\circ} \mathrm{C}$ and the end of the measurement, with a mineral origin.

During the oxidation stage, the $\mathrm{CO}_{2}$ production curve exhibits, when the rock contains carbonates, a minimum 


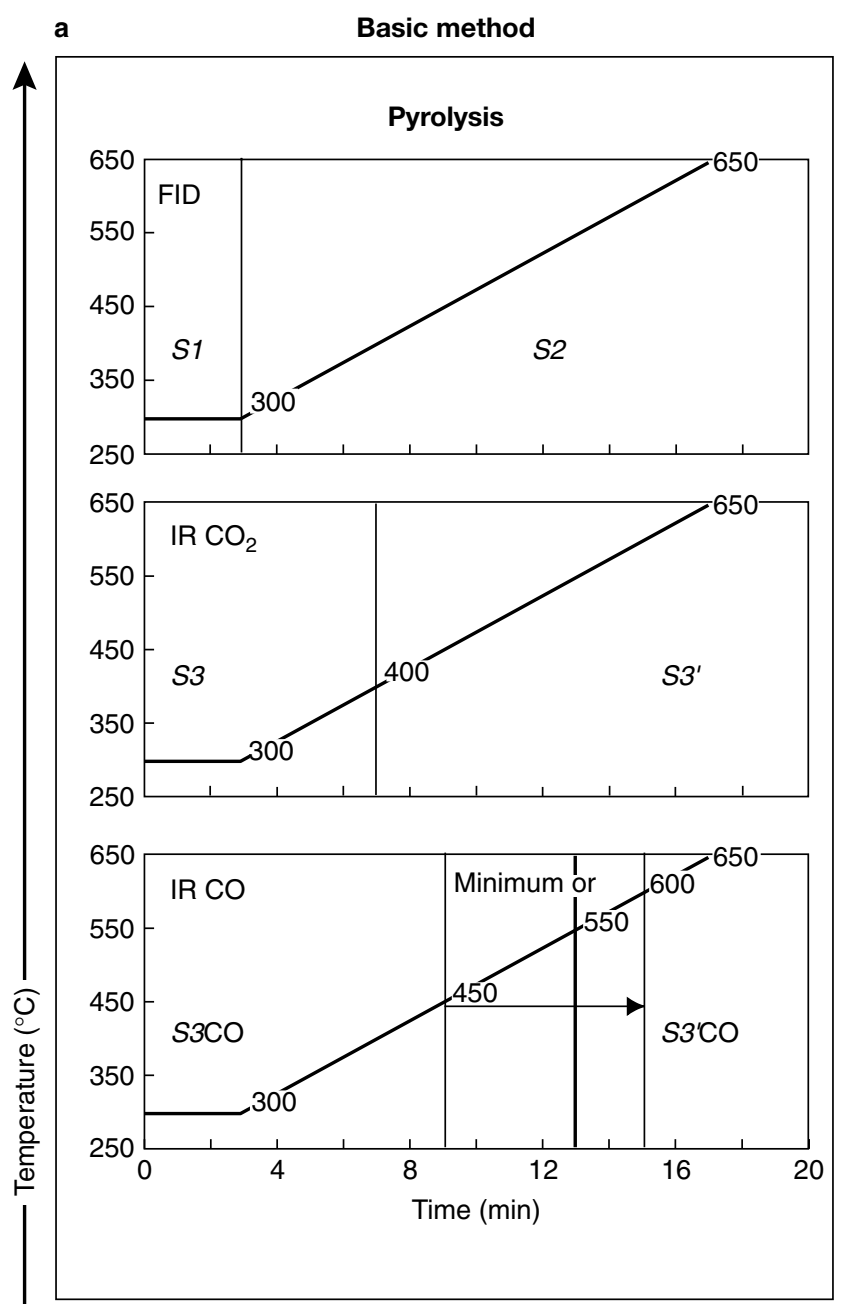

b

Pure organic matter method
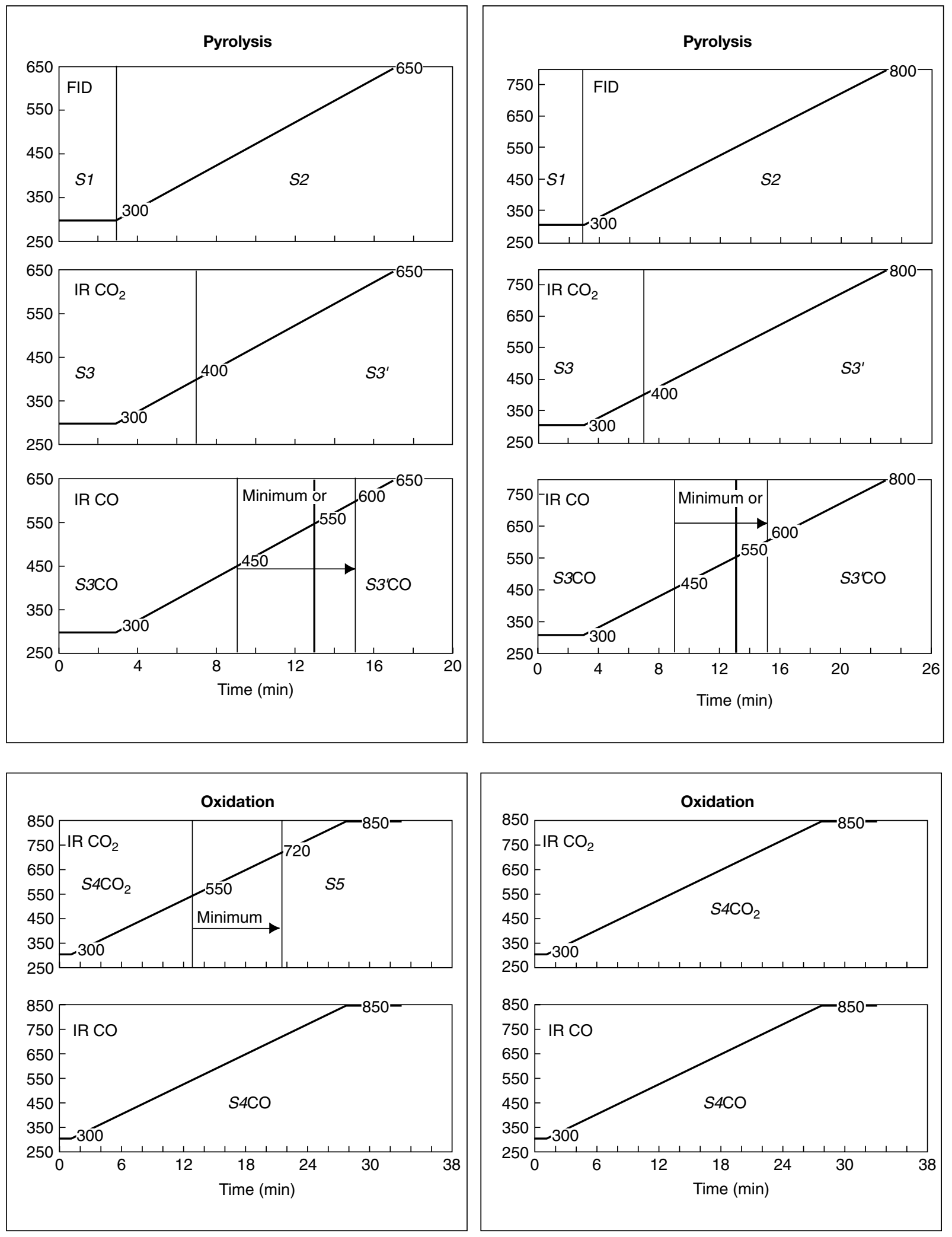

Figure 3

Description of the Rock-Eval 6 methods for source rocks (a) and pure organic matter (b). 
TABLE 2a

Acquisition parameters for the Basic Method

\begin{tabular}{c|c|c|c}
\hline Acquisition parameters & Detector/Oven & Unit & Name \\
\hline$S 1$ & FID/Pyrolysis & $\mathrm{mg} \mathrm{HC} / \mathrm{g}$ rock & Free hydrocarbons \\
$S 2$ & FID/Pyrolysis & $\mathrm{mg} \mathrm{HC} / \mathrm{g}$ rock & Oil potential \\
$T p S 2$ & - & ${ }^{\circ} \mathrm{C}$ & Temperature of peak $S 2$ maximum \\
$S 3$ & IR/Pyrolysis & $\mathrm{mg} \mathrm{CO}_{2} / \mathrm{g}$ rock & $\mathrm{CO}_{2}$ organic source \\
$S 3$, & IR/Pyrolysis & $\mathrm{mg} \mathrm{CO}_{2} / \mathrm{g}$ rock & $\mathrm{CO}_{2}$ mineral source \\
$T p S 3$, & - & ${ }^{\circ} \mathrm{C}$ & Temperature of peak $S 3^{\prime}$ maximum \\
$S 3 \mathrm{CO}$ & IR/Pyrolysis & $\mathrm{mg} \mathrm{CO} / \mathrm{g}$ rock & $\mathrm{CO}_{2}$ organic source \\
$T p S 3 \mathrm{CO}$ & - & ${ }^{\circ} \mathrm{C}$ & Temperature of peak $S 3 \mathrm{CO}$ maximum \\
$S 3{ }^{\prime} \mathrm{CO}$ & IR/Pyrolysis & $\mathrm{mg} \mathrm{CO} / \mathrm{g}$ rock & CO organic and mineral source \\
$S 4 \mathrm{CO} 2$ & IR/Oxidation & $\mathrm{mg} \mathrm{CO} / \mathrm{g}$ rock & $\mathrm{CO}_{2}$ organic source \\
$S 5$ & IR/Oxidation & $\mathrm{mg} \mathrm{CO} / \mathrm{g}$ rock & $\mathrm{CO}_{2}$ mineral source \\
$T p S 5$ & - & ${ }^{\circ} \mathrm{C}$ & Temperature of peak $S 5$ maximum \\
$S 4 \mathrm{CO}$ & IR/Oxidation & $\mathrm{mg} \mathrm{CO} / \mathrm{g}$ rock & $\mathrm{CO}$ organic source $^{2}$
\end{tabular}

TABLE $2 b$

Calculated parameters for the Basic Method

\begin{tabular}{|c|c|c|c|}
\hline Calculated parameters & Unit & Formula & Name \\
\hline $\operatorname{Tmax}$ & ${ }^{\circ} \mathrm{C}$ & $T p S 2-\Delta T m a x^{*}$ & $\operatorname{Tmax}$ \\
\hline PI & & $\frac{S 1}{(S 1+S 2)}$ & Production index \\
\hline $\mathrm{PC}$ & $\mathrm{wt} \%$ & $\frac{[(S 1+S 2) \times 0,83]+\left[S 3 \times \frac{12}{44}\right]+\left[\left(S 3 \mathrm{CO}+\frac{S 3^{\prime} \mathrm{CO}}{2}\right) \times \frac{12}{28}\right]}{10}$ & Pyrolysable org. carbon \\
\hline $\mathrm{RCCO}$ & $\mathrm{wt} \%$ & $\frac{S 4 \mathrm{CO} \times \frac{12}{28}}{10}$ & Residual org. carbon (CO) \\
\hline $\mathrm{RC} \mathrm{CO}_{2}$ & $\mathrm{wt} \%$ & $\frac{S 4 \mathrm{CO}_{2} \times \frac{12}{44}}{10}$ & Residual org. carbon $\left(\mathrm{CO}_{2}\right)$ \\
\hline $\mathrm{RC}$ & $\mathrm{wt} \%$ & $\mathrm{RCCO}+\mathrm{RC} \mathrm{CO}_{2}$ & Residual org. carbon \\
\hline TOC & wt $\%$ & $\mathrm{PC}+\mathrm{RC}$ & Total organic carbon \\
\hline S1/TOC & $\mathrm{mg} \mathrm{HC} / \mathrm{g}$ TOC & $\frac{S 1 \times 100}{\mathrm{TOC}}$ & \\
\hline HI & $\mathrm{mg} \mathrm{HC} / \mathrm{g}$ TOC & $\frac{S 2 \times 100}{\mathrm{TOC}}$ & Hydrogen index \\
\hline OI & $\mathrm{mg} \mathrm{CO}_{2} / \mathrm{g}$ TOC & $\frac{S 3 \times 100}{\text { TOC }}$ & Oxygen index \\
\hline $\mathrm{OI} \mathrm{CO}$ & $\mathrm{mg} \mathrm{CO} / \mathrm{g}$ TOC & $\frac{S 3 \mathrm{CO} \times 100}{\mathrm{TOC}}$ & Oxygen index $\mathrm{CO}$ \\
\hline PyroMinC & $\mathrm{wt} \%$ & $\frac{\left[S 3^{\prime} \times \frac{12}{44}\right]+\left[\left(\frac{S 3^{\prime} \mathrm{CO}}{2}\right) \times \frac{12}{28}\right]}{10}$ & Pyrolysis mineral carbon \\
\hline OxiMinC & $\mathrm{wt} \%$ & $\frac{S 5 \times \frac{12}{44}}{10}$ & Oxidation mineral carbon \\
\hline MinC & $\mathrm{wt} \%$ & PyroMinC + OxiMinC & Mineral carbon \\
\hline
\end{tabular}

* $\Delta$ Tmax is calculated when calibrating apparatus and results from the difference between $T p S 2$ of standard 55000 and its accepted $T m a x$ ( $419^{\circ} \mathrm{C}$ ) determined after RockEval 2 measurements. $\Delta \operatorname{Tmax}=T p S 2_{\text {std }} 55000-\operatorname{Tmax}$ accepted 55000 . 
between $550^{\circ}$ and $720^{\circ} \mathrm{C}$. Thus, the $S 4 \mathrm{CO}_{2}$ corresponds to the amount of $\mathrm{CO}_{2}$ generated between $300^{\circ} \mathrm{C}$ and the temperature of the defined minimum (organic origin of carbon) and $S 5$ corresponds to the counterpart up to the end of the measurement (mineral origin of carbon).

The calculations of the total organic and mineral carbon content are described in Table $2 \mathrm{~b}$ and illustrated in Figures $4 \mathrm{a}$ and $4 \mathrm{~b}$.

The upper temperature of $650^{\circ} \mathrm{C}$ for pyrolysis of source rocks was chosen in order to obtain a complete $S 2$ signal while a minimum of carbonates will decompose during this step. In these conditions, coals, which are generating late methane and contain few carbonates, will be preferentially analyzed under the organic matter method (pyrolysis up to $\left.800^{\circ} \mathrm{C}\right)$.

\subsubsection{IFP Acquisition Method for Coals and Isolated Organic Matter}

As for source rocks, two steps are performed when running the method called Pure Organic Matter: pyrolysis and combustion. The final pyrolysis temperature is $800^{\circ} \mathrm{C}$ instead of $650^{\circ} \mathrm{C}$. Thus, it is not possible to have a direct comparison of the residual organic carbon for the two methods. The same is true for the $\mathrm{CO}_{2}$ and $\mathrm{CO}$ total yields obtained during pyrolysis except for $S 3$ and $S 3 \mathrm{CO}$ which are quantified in the same temperature range (Fig. $3 b$ ).

Since i.o.m. does not contain minerals anymore, the total integrated signals for the FID, the $\mathrm{CO}$ and $\mathrm{CO}_{2}$ during both the pyrolysis and oxidation stages give directly the value for the TOC as follows:

$$
\begin{aligned}
\operatorname{TOC}(\%) & =[(0.83 * S 1)+(0.83 * S 2) \\
& +\left(12 / 44 *\left(S 3+S 3^{\prime}+S 4 \mathrm{CO}_{2}\right)\right) \\
& \left.+\left(12 / 28 *\left(S 3 \mathrm{CO}+S 3^{\prime} \mathrm{CO}+S 4 \mathrm{CO}\right)\right)\right] / 10
\end{aligned}
$$

However, it is still possible to discriminate between the pyrolysable and residual organic carbon (PC and RC, respectively) because two distinct signals are recorded, one during pyrolysis and one during oxidation.

\subsubsection{Comparison with Rock-Eval 2 Method}

As said in the Introduction, one of the aims of the present study is to compare data acquired with the Rock-Eval 6 and

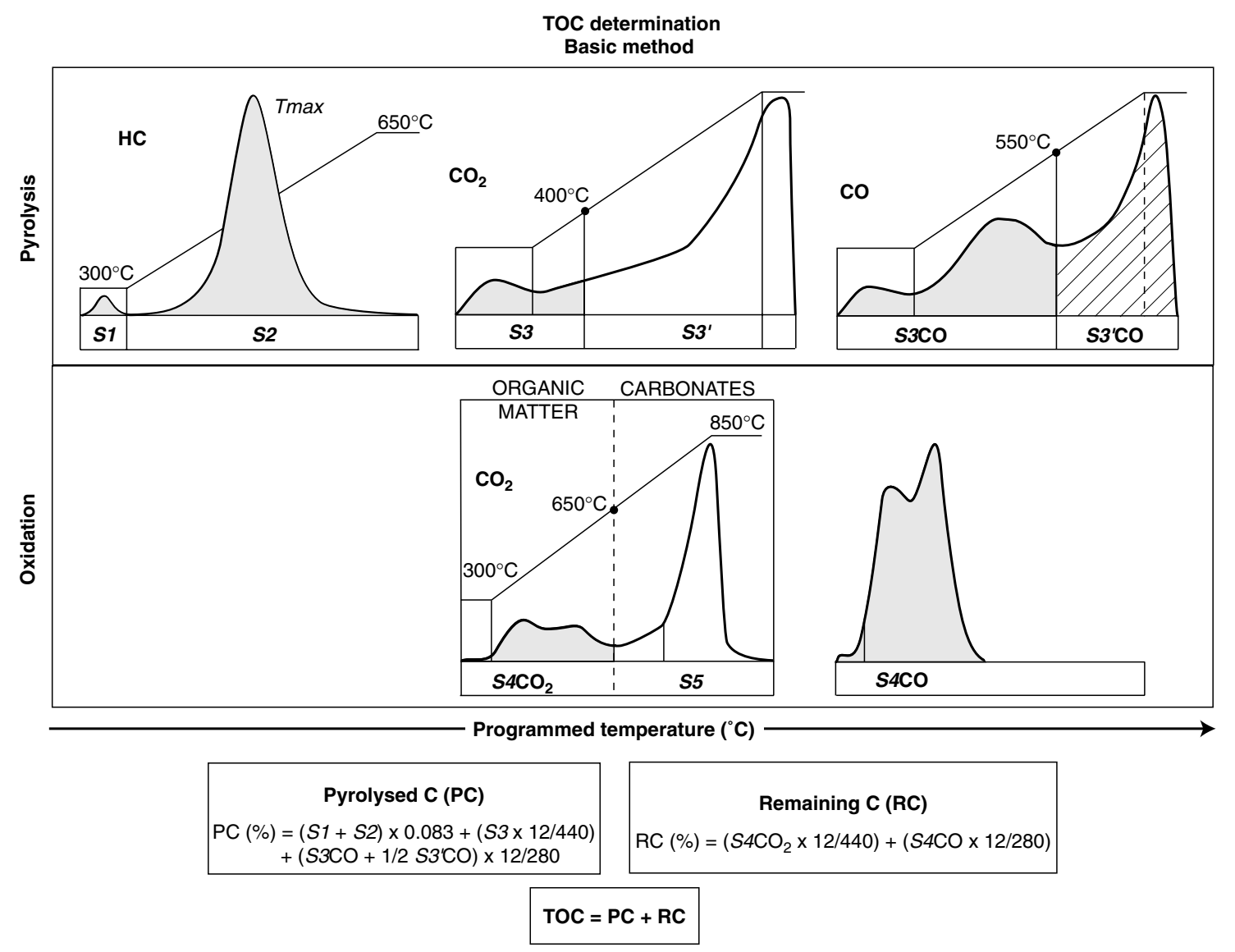

Figure 4a

Analytical procedure for calculating the TOC by Rock-Eval 6 . 


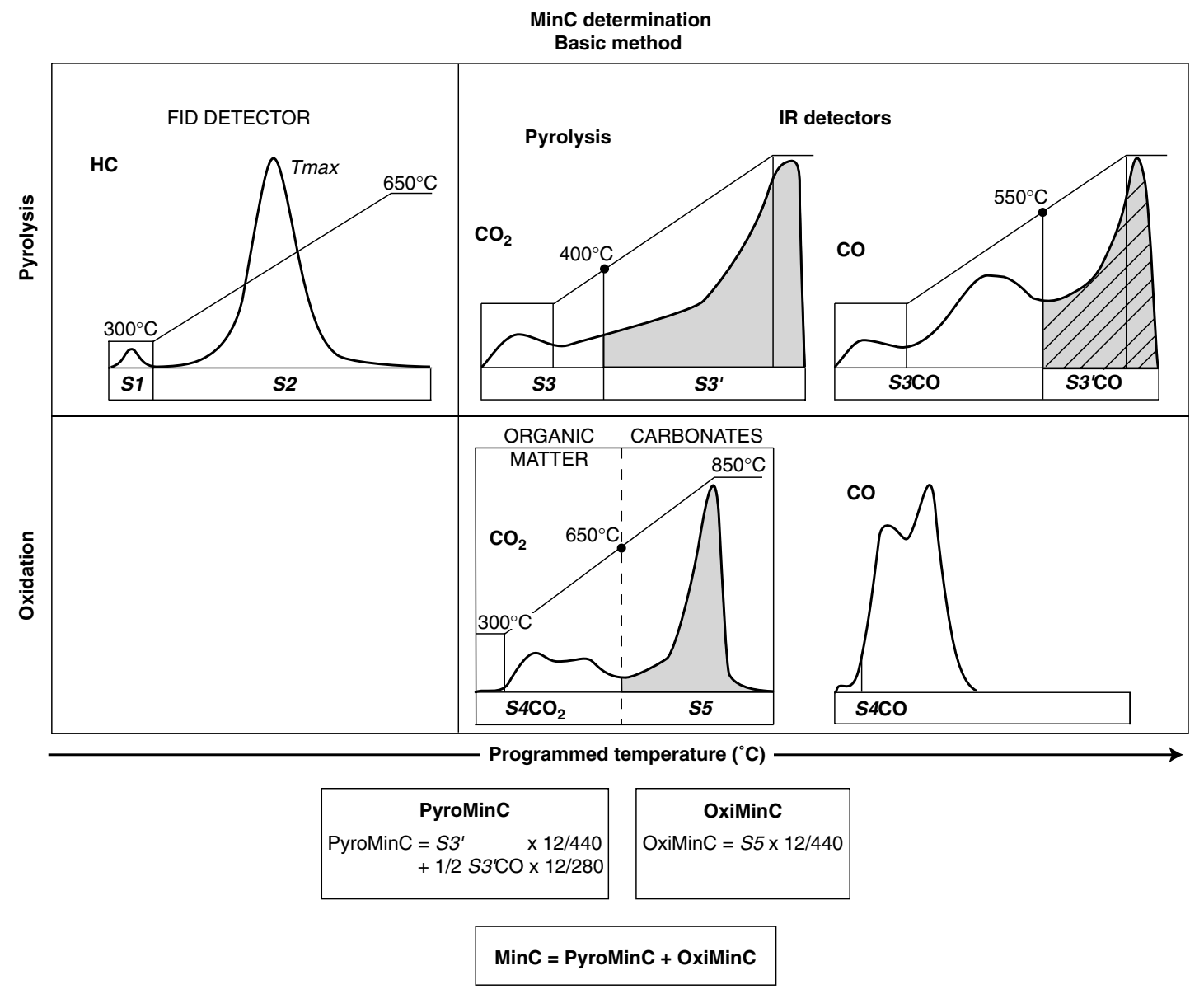

Figure 4b

Analytical procedure for calculating the MinC by Rock-Eval 6.

the previous technology, i.e. Rock-Eval 2 (Espitalié et al., 1985a, 1985b, 1985c). The parameters measured in the Rock-Eval 2 are described in Figure 5 and compared to those determined by the Rock-Eval 6.

In the Rock-Eval 2, the probe is not in direct contact with the crucible but inserted in the oven wall. As a consequence, the recorded Tmax is the oven temperature when the $S 2$ peak maximum is reached, which is different from the effective temperature of the sample, and corrections were proposed by Espitalié et al. (1985a, 1985b, 1985c). In these conditions, the Tmax reproducibility is highly dependent on the apparatus setup and calibration. In the Rock-Eval 6 the probe is in direct contact with the crucible, a precise measurement of the sample temperature is obtained when the $S 2$ peak maximum is reached (TpS2). The Tmax is then calculated after $T p S 2$ and $\Delta$ Tmax which is the direct comparison of TpS2 of standard 55000 determined during calibration and its accepted Tmax (established after Rock-Eval 2 measurements). The value of $T p S 2$ being dependent on the rate of the pyrolysis, the Tmax value is significant only for pyrolyses run at $25^{\circ} \mathrm{C}$ per minute.
The $S 1$ peak is obtained in the same conditions for RockEval 6 and Rock-Eval 2. However, as temperature is measured in the oven wall, the real sample temperature during this isothermal step is different from $300^{\circ} \mathrm{C}\left(20^{\circ} \mathrm{C}\right.$ variations can be observed depending on apparatus setup). As a consequence, the $S 1$ measured with Rock-Eval 2 can be different from the $S 1$ measured with Rock-Eval 6.

For quantification of the $S 2$ surface, pyrolysis is run between $300^{\circ}$ and $600^{\circ} \mathrm{C}$ for Rock-Eval 2 (instead of $650^{\circ} \mathrm{C}$ for Rock-Eval 6). Thus, when the $S 2$ surface is not completed at $600^{\circ} \mathrm{C}$, an underestimation of this parameter should be expected (especially for mature Type III organic matter). As a whole, since the temperature measurement is different, comparisons of the $S 1$ and $S 2$ surfaces between the two apparatus may display inconsistencies. Nevertheless, the total amount $S 1+S 2$ may be similar.

The carrier gas for the Rock-Eval 2 is helium and has been replaced by nitrogen in the Rock-Eval 6. In the present study, the influence of the carrier gas was studied with a RockEval 6 run with helium as carrier gas on a reference sample. 
120

Oil \& Gas Science and Technology -Rev. IFP, Vol. 56 (2001), No. 2

Rock-Eval 2

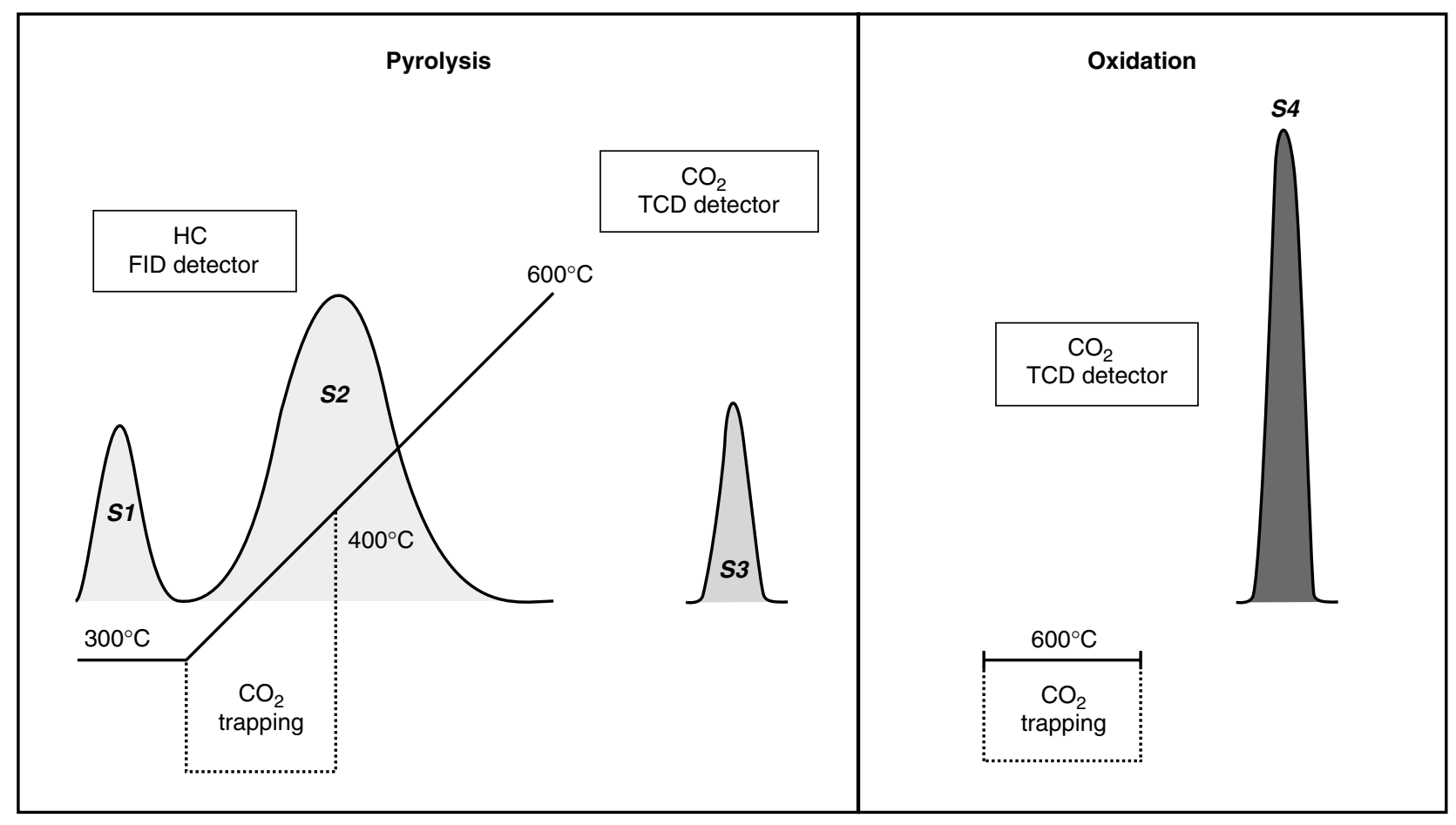

Rock-Eval 6

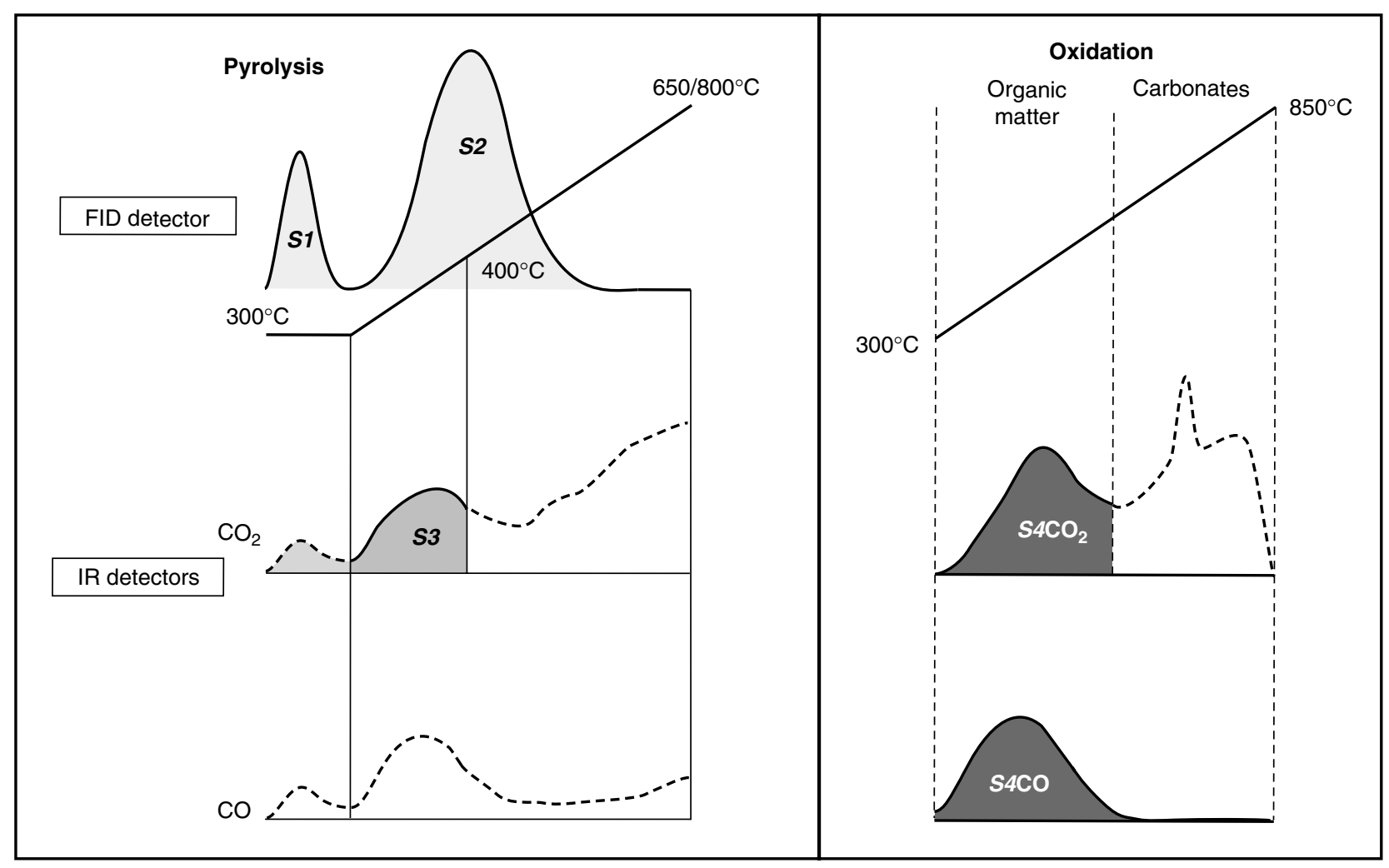

Figure 5

Comparison between Rock-Eval 2 and Rock-Eval 6 pyrolysis conditions. 
The Rock-Eval 2 is equipped with a catharometer detector for measurement of $\mathrm{CO}_{2}$ released during pyrolysis. This gas is not recorded continuously: it is trapped from the beginning of pyrolysis up to $400^{\circ} \mathrm{C}$ (Fig. 5). Then, it is released and quantified at once. This value can be directly compared to the S3 surface measured by Rock-Eval 6 .

The $\mathrm{CO}$ curve is not recorded at all, thus preventing any comparison with Rock-Eval 6 for CO data.

With the standard version of the Rock-Eval 2, it is not possible to determine the total organic carbon. However, Rock-Eval 2 can be equipped with a "carbon module" which enables to oxidize the residual rock after pyrolysis. In that case, it is assumed that carbonate decomposition has not yet started at $600^{\circ} \mathrm{C}$.

In the present study, the available Rock-Eval 2 was not equipped for TOC measurements. Moreover, analyses were run in the Geochemistry Section in Petrobras (Brazil) where only Types I and II samples are usually analyzed. Thus, the two series of coals selected for the present study were not included in these comparisons.

\subsection{Verification of the TOC for Bulk Rock, Isolated Organic Matter and S2 Peak}

As indicated in the Introduction (Fig. 1), the TOC measured by Rock-Eval 6 was verified through alternative techniques on bulk source rocks and i.o.m. (kerogen). For kerogens, a direct comparison was done between the TOC measured by the Rock-Eval and the carbon content measured as the $\mathrm{CO}_{2}$ amount recovered after oxidation at $1000^{\circ} \mathrm{C}$ and quantified by the use of a thermal conductivity detector. For bulk source rock, the TOC can be estimated by combining the TOC measured on the corresponding i.o.m. and the ratio between the initial amount of rock before mineral destruction and that of the i.o.m. after this acidic treatment. The TOC measured by Leco on decarbonated rocks can be also compared to that obtained by Rock-Eval 6. Finally, the TOC content of the $S 2$ peak was determined on kerogen samples of various organic matter types through preparative pyrolysis.

In this section are described the procedure for mineral destruction; the elemental analyses; the Leco apparatus; and the preparative pyrolysis technique for the recovery of the $\mathrm{C}_{6}{ }^{+} \mathrm{S} 2$ peak.

\subsubsection{Isolated Organic Matter Preparation}

The sample amount for each kerogen (i.o.m.) preparation depends on the initial TOC of the bulk rock. For low TOC samples $(<2 \mathrm{wt} \%)$, at least $50 \mathrm{~g}$ are submitted to acidic treatment whereas less than $10 \mathrm{~g}$ are needed for samples with higher TOC. i.o.m. was prepared according to the protocol developed by Durand and Nicaise (1980), i.e. by successive acid treatments $(\mathrm{HCl}$ and $\mathrm{HF})$ under inert atmosphere $\left(\mathrm{N}_{2}\right)$ at $80^{\circ} \mathrm{C}$ followed by water washings. Special care is given to washings in order to ensure dissolution of newly formed fluorosilicates, and that would interfere with elemental analyses of kerogens. Recovered kerogens are dried at $100^{\circ} \mathrm{C}$ under nitrogen flow, ground, weighed, and stored. Besides isolated matter, pyrite and heavy metal oxides, if present, are recovered by this procedure and quantified by elemental analyses.

\subsubsection{Elemental Analyses}

All the elemental analyses were done by an external specialized laboratory.

For i.o.m., the following elements were estimated in wt $\%$ of the sample: $\mathrm{C}, \mathrm{H}, \mathrm{N}, \mathrm{O}$, total $\mathrm{S}$ and $\mathrm{Fe}$. Ashes (combustion residues) were weighed in order to crosscheck the obtained data. All determinations were doubled or tripled according to preset reproducibility criteria.

$\mathrm{C}, \mathrm{H}$ and $\mathrm{N}$ were determined on one aliquot of the kerogen by use of a thermal conductivity detector on gases resulting from combustion at $1000^{\circ} \mathrm{C}$. $\mathrm{O}$ is measured on a different aliquot by pyrolyzing the kerogen under nitrogen flow: pyrolysis gases are reduced on carbon into carbon monoxide, which is oxidized in carbon dioxide and finally quantified by coulometry. Total $S$ (including pyritic and organic $S$ ) is obtained by oxidation of a third aliquot of kerogen and quantification of sulfur dioxide by coulometry. The determination of $\mathrm{Fe}$ is necessary to calculate the amount of pyrite (FeS2) in the sample and, by mass balance, the mineral and organic sulfur. This analysis is done on a fourth aliquot by mineralization of the sample in a mixture of nitric and sulfuric acids, then quantification of $\mathrm{Fe}$ is done by atomic absorption.

In Table 3 are given duplicate data of all measured elements on four aliquots of a kerogen selected in the IFP data base together with the standard deviation and relative error (wt $\%)$ of the average values. The sum $(\Sigma \mathrm{m})$ of average values is not equal to $100 \mathrm{wt} \%$ due to the contribution of elements which were not analyzed but present at very low concentrations. Thus, presented data were not normalized data and the raw carbon determined by elemental analysis can be directly compared to that measured by Rock-Eval 6 .

Once the organic carbon content of the i.o.m. is known, it is possible to determine the absolute amount of organic carbon in the source rocks $\left(\mathrm{C}_{0}\right)$ before acidic digestion by the following equation:

with:

$$
\mathrm{C}_{0}=\left(\mathrm{IOM} * \mathrm{C}_{\mathrm{i} . \mathrm{o} . \mathrm{m} .}\right) / \mathrm{R}_{0}
$$

$\mathrm{C}_{0} \quad$ calculated organic carbon of the initial source rock

$\mathrm{R}_{0} \quad$ initial weight of bulk rock before kerogen isolation

IOM mass of the i.o.m. and/or pyrite recovered after acidic treatment

$\mathrm{C}_{\text {i.o.m. }}$ carbon content of the i.o.m. 
TABLE 3

Duplicate elemental analyses on four aliquots of the same kerogen and calculation of the standard deviation and relative error for the average values

\begin{tabular}{r|c|c|c|c|c|c|c|c|c|c|c|c|c|c|c|c|c|c|c}
\hline & $\mathbf{C}(\mathbf{a})$ & $\mathbf{C}(\mathbf{b})$ & $\mathbf{C}(\mathbf{m})$ & $\mathbf{H}(\mathbf{a})$ & $\mathbf{H}(\mathbf{b})$ & $\mathbf{H}(\mathbf{m})$ & $\mathbf{N}(\mathbf{a})$ & $\mathbf{N}(\mathbf{b})$ & $\mathbf{N}(\mathbf{m})$ & $\mathbf{O}(\mathbf{a})$ & $\mathbf{O}(\mathbf{b})$ & $\mathbf{O}(\mathbf{m})$ & $\mathbf{S}(\mathbf{a})$ & $\mathbf{S}(\mathbf{b})$ & $\mathbf{S}(\mathbf{m})$ & $\mathbf{F e}(\mathbf{a})$ & $\mathbf{F e}(\mathbf{b})$ & $\mathbf{F e}(\mathbf{m})$ & $\sum \mathbf{m}$ \\
\hline 1 & 60.75 & 60.78 & $\mathbf{6 0 . 8}$ & 6.26 & 6.21 & $\mathbf{6 . 2}$ & 1.51 & 1.50 & $\mathbf{1 . 5}$ & 8.28 & 8.21 & $\mathbf{8 . 3}$ & 12.65 & 12.66 & $\mathbf{1 2 . 7}$ & 8.10 & 8.60 & $\mathbf{8 . 4}$ & $\mathbf{9 7 . 8}$ \\
2 & 60.66 & 60.77 & $\mathbf{6 0 . 7}$ & 6.32 & 6.36 & $\mathbf{6 . 3}$ & 1.53 & 1.57 & $\mathbf{1 . 6}$ & 8.53 & 8.36 & $\mathbf{8 . 5}$ & 12.56 & 12.83 & $\mathbf{1 2 . 7}$ & 8.40 & 8.15 & $\mathbf{8 . 3}$ & $\mathbf{9 8 . 0}$ \\
3 & 60.18 & 60.13 & $\mathbf{6 0 . 2}$ & 6.36 & 6.27 & $\mathbf{6 . 3}$ & 1.49 & 1.48 & $\mathbf{1 . 5}$ & 8.52 & 8.39 & $\mathbf{8 . 5}$ & 12.18 & 12.83 & $\mathbf{1 2 . 5}$ & 7.80 & 8.25 & $\mathbf{8 . 0}$ & $\mathbf{9 7 . 0}$ \\
4 & 60.52 & 60.36 & $\mathbf{6 0 . 4}$ & 6.30 & 6.30 & $\mathbf{6 . 3}$ & 1.58 & 1.47 & $\mathbf{1 . 5}$ & 8.87 & 8.83 & $\mathbf{8 . 9}$ & 12.44 & 12.40 & $\mathbf{1 2 . 4}$ & 8.50 & 8.40 & $\mathbf{8 . 5}$ & $\mathbf{9 8 . 0}$ \\
\hline
\end{tabular}

This calculated $\mathrm{C}_{0}$ can be directly compared to TOC determined either by Leco or Rock-Eval 6 techniques on the bulk rock.

The i.o.m. comprises the insoluble residue, i.e. kerogen and free petroleum products, i.e. bulk rock extracts. Unfortunately, all available i.o.m. samples were stored after solvent (dichloromethane, DCM) extraction and in most cases, the extract yield is unknown. However, we have corrected the carbon content by taking into account at least the carbon contained in the $S 1$ peak measured by RockEval 6. Since the weight of this extract is always very small, the correction was very minor except for samples with accumulated petroleum which were systematically excluded for this type of correlation.
Since $\mathrm{C}_{0}$ is the only parameter which enables to check the TOC value measured by Rock-Eval 6, it was necessary to determine the accuracy of its measurement. For this purpose, a bulk rock available in large amount was selected in the IFP data base. Several tests of organic matter isolation for the two sizes of reactor used for kerogen preparation were run. Then, for each aliquot of bulk rock, the insoluble organic matter was weighed and submitted to elemental analyses for triplicate carbon measurements. The resulting average value was used to calculate the $\mathrm{C}_{0}$.

Results given in Table 4 show that the i.o.m. recovery does not depend on the initial amount of source rock: the same yield is obtained when 50 or $10 \mathrm{~g}$ are treated and the relative error on that estimation is only $1.5 \%$. The accuracy

TABLE 4

Relative error for $\mathrm{C}_{0}$ estimation

\begin{tabular}{|c|c|c|c|c|c|c|c|}
\hline \multirow{2}{*}{$\mathbf{R}_{\mathbf{0}}(\mathbf{g})$} & \multicolumn{2}{|c|}{ i.o.m. } & \multirow{2}{*}{ C(a) (\%) } & \multirow{2}{*}{$\mathrm{C}(\mathrm{b})(\%)$} & \multirow{2}{*}{ C(c) (\%) } & \multirow{2}{*}{$\mathrm{C}(\mathrm{m})(\%)$} & \multirow{2}{*}{$\mathrm{C}_{0}(\%)$} \\
\hline & (g) & $(\%)$ & & & & & \\
\hline 50.6100 & 5.5685 & 11.0 & 60.51 & 61.50 & 61.22 & 61.1 & 6.7 \\
\hline 50.2164 & 5.6473 & 11.2 & 61.40 & 60.34 & 60.54 & 60.8 & 6.8 \\
\hline 50.2658 & 5.3766 & 10.7 & 60.66 & 59.65 & 60.99 & 60.4 & 6.5 \\
\hline 10.0789 & 1.1172 & 11.1 & 59.87 & 60.15 & 60.77 & 60.3 & 6.7 \\
\hline 10.0899 & 1.1283 & 11.2 & 61.46 & 61.36 & 60.99 & 61.3 & 6.9 \\
\hline 10.0007 & 1.1130 & 11.1 & 60.83 & 60.68 & 60.88 & 60.8 & 6.8 \\
\hline 10.0012 & 1.1190 & 11.2 & 60.80 & 61.02 & 61.32 & 61.0 & 6.8 \\
\hline 10.0008 & 1.1188 & 11.2 & 60.66 & 60.77 & 61.13 & 60.9 & 6.8 \\
\hline 10.0016 & 1.1024 & 11.0 & 60.18 & 60.13 & 59.73 & 60.0 & 6.6 \\
\hline 10.0008 & 1.1067 & 11.1 & 60.52 & 60.36 & 60.61 & 60.5 & 6.7 \\
\hline 10.0010 & 1.1146 & 11.1 & 60.94 & 60.78 & 60.18 & 60.6 & 6.8 \\
\hline 10.0011 & 1.1466 & 11.5 & 60.35 & 60.31 & 59.92 & 60.2 & 6.9 \\
\hline 10.0036 & 1.1283 & 11.3 & 60.63 & 60.82 & 60.12 & 60.5 & 6.8 \\
\hline 10.0012 & 1.1173 & 11.2 & 59.80 & 60.01 & nd & 59.9 & 6.7 \\
\hline 10.0028 & 1.1001 & 11.0 & 60.71 & 60.54 & nd & 60.6 & 6.7 \\
\hline 10.0006 & 1.1242 & 11.2 & 59.25 & 60.87 & 60.69 & 60.3 & 6.8 \\
\hline \multicolumn{2}{|c|}{ Average value } & 11.1 & 60.5 & 60.6 & 60.6 & 60.6 & 6.7 \\
\hline \multicolumn{2}{|c|}{ Standard deviation } & 0.2 & 0.6 & 0.5 & 0.5 & 0.4 & 0.1 \\
\hline \multicolumn{2}{|c|}{ Relative error (\%) } & 1.5 & 0.9 & 0.8 & 0.8 & 0.6 & 1.6 \\
\hline
\end{tabular}


of carbon measurement by elemental analysis is excellent since the relative error on triplicate sets is $0.6 \%$. The resulting $\mathrm{C}_{0}$ calculated value is given with an error of $1.6 \%$.

In conclusion, $\mathrm{C}_{0}$ is precisely determined and thus can be used as a reliable parameter for checking the TOC measured by Rock-Eval 6.

This calculation was not done for coals in which the MinC was less than $1 \mathrm{wt} \%$ because for these samples the TC measured by elemental analysis corresponds to the organic carbon and thus can be directly correlated to the Rock-Eval 6 data. The same is true for kerogens for which the organic carbon measured by elemental analysis was labeled $\mathrm{C}_{k}$. For these coals and kerogens, besides carbon content measurement, determination of the oxygen content was of special interest when plotting a HI/OI (hydrogen index $v s$. oxygen index) diagram as a function of the organic matter and maturity stage (Espitalié et al., 1985a, 1985b, 1985c). Unfortunately, the selected kerogens were prepared a long time ago (some weeks to some years ago) and had undergone chemical alteration resulting in a systematic increase of their oxygen content and as a counterpart in the decrease of the carbon percentage. Consequently, kerogens were resubmitted to elemental analyses in parallel with Rock-Eval 6 analysis.

Our experimental correlation could have been done between the new oxygen content and the yield of $\mathrm{CO}$ and $\mathrm{CO}_{2}$ but it would obviously have no geochemical meaning. However, since our kerogens were prepared at various times in the past, it was possible to quantify this chemical artifact $v s$. time and to propose recommendations for future coal and kerogen storage.

Data on Type II kerogens are reported in Table 5. They clearly show that for less than three to four years, the H/C has not significantly changed whereas the atomic ratio $\mathrm{O} / \mathrm{C}$ may increase between $20 \%$ and $60 \%$. When the storage time is doubled ( 8 years), the $\mathrm{O} / \mathrm{C}$ ratio is multiplied by between 2 and 6 and the $\mathrm{H} / \mathrm{C}$ ratio is significantly increased.

As a consequence, it was not possible to compare the $S 3$ peak measured by Rock-Eval 2 and Rock-Eval 6 because most of samples selected in this study were provided by Petrobras and the Rock-Eval 2 analyses were performed at various times in the past. Since all Rock-Eval 6 analyses were done this year, alteration of our kerogen set precludes any $S 3$ comparison between Rock-Eval 2 and Rock-Eval 6 in the framework of the present study.

TC, which corresponds to the sum of the organic and mineral carbon, was also determined by elemental analysis on most of selected bulk rocks. In that case, the rock sample was submitted to a combustion at $1050^{\circ} \mathrm{C}$. This temperature being much higher than that of the Rock-Eval 6 program, this measurement is a very good crosscheck of the TC. Knowing $\mathrm{TC}$ and $\mathrm{C}_{0}$, it is possible to determine the theoretical value for mineral carbon content $\left(\mathrm{MinC}_{0}\right)$ which can be directly compared to MinC measured by Rock-Eval 6 .

\subsubsection{Determination of Organic Carbon by the Leco SC-444 Equipment}

The Leco SC-444 analyzer, equipped with infra-red detectors, was designed to measure carbon and sulfur content in a large variety of organic materials such as coal, coke and oil, as well as in inorganic materials including soil, cement and limestone.

An amount of $0.25 \mathrm{~g}$ is placed in a crucible made of porous porcelain, which is introduced into the combustion furnace. The samples are burned in an oxygen atmosphere at $1350^{\circ} \mathrm{C}$, with a constant oxygen flow. Reduced carbon and sulfur contained in the sample are oxidized, thus producing $\mathrm{CO}_{2}$ and $\mathrm{SO}_{2}$. These gases are then swept from the sample and carried to the analyzer. After passing through two tubes containing magnesium perchlorate for the retention of

TABLE 5

Influence of time on $\mathrm{H} / \mathrm{C}$ and $\mathrm{O} / \mathrm{C}$ atomic ratios for kerogens of three different series of type II during storage under ambient air

\begin{tabular}{|c|c|c|c|c|c|c|c|}
\hline \multirow{2}{*}{ Date 1} & \multirow{2}{*}{ Date 2} & \multirow{2}{*}{$\begin{array}{c}\Delta t \\
\text { (months) }\end{array}$} & \multicolumn{2}{|c|}{$\mathrm{H} / \mathrm{C}$ atomic ratio } & \multicolumn{3}{|c|}{$\mathrm{O} / \mathrm{C}$ atomic ratio } \\
\hline & & & 1 & 2 & 1 & 2 & $2 / 1$ \\
\hline \multirow[t]{4}{*}{$29 / 11 / 96$} & \multirow[t]{4}{*}{$16 / 03 / 00$} & \multirow[t]{4}{*}{40} & 1.17 & 1.19 & 0.115 & 0.146 & 1.27 \\
\hline & & & 1.05 & 1.07 & 0.066 & 0.091 & 1.38 \\
\hline & & & 0.89 & 0.91 & 0.036 & 0.046 & 1.28 \\
\hline & & & 0.86 & 0.89 & 0.062 & 0.076 & 1.23 \\
\hline \multirow[t]{3}{*}{$19 / 06 / 97$} & \multirow[t]{3}{*}{$29 / 02 / 00$} & \multirow[t]{3}{*}{32} & 1.11 & 1.10 & 0.215 & 0.266 & 1.24 \\
\hline & & & 1.10 & 1.13 & 0.171 & 0.235 & 1.37 \\
\hline & & & 0.79 & 0.79 & 0.057 & 0.089 & 1.56 \\
\hline \multirow[t]{5}{*}{ 24/03/92 } & \multirow[t]{5}{*}{$29 / 02 / 00$} & \multirow[t]{5}{*}{95} & 1.28 & 1.31 & 0.084 & 0.181 & 2.15 \\
\hline & & & 1.05 & 1.17 & 0.065 & 0.248 & 3.82 \\
\hline & & & 0.85 & 0.97 & 0.057 & 0.190 & 3.33 \\
\hline & & & 0.60 & 0.79 & 0.070 & 0.412 & 5.89 \\
\hline & & & 0.58 & 0.76 & 0.075 & 0.302 & 4.02 \\
\hline
\end{tabular}


humidity, and by one flow controller, $\mathrm{CO}_{2}$ and $\mathrm{SO}_{2}$ are measured by two specific infra-red detectors. Measured concentrations (expressed in percentages or parts per million) are calculated by a software which takes into account sample weight, calibration and humidity values. In this paper, C concentrations measured by Leco analyzer are expressed in percentages and labeled $\mathrm{C}_{\text {leco }}$.

\subsubsection{Preparative Pyrolysis}

Preparative pyrolysis experiments were carried out in order to recover the $\mathrm{C}_{6}-\mathrm{C}_{14}$ and $\mathrm{C}_{14}{ }^{+}$fractions of the $S 2$ peak and measure their composition. The knowledge of their carbon content is important for the calculations of organic carbon by Rock-Eval 6.

The preparative pyrolysis device is a cylindrical minifurnace coated with gold to avoid wall effects, as described in previous publications (Behar and Pelet, 1985; Behar et al., 1989). 20-30 mg of kerogen loaded on a gold rod were introduced into the pyrolysis chamber under argon flow. After a preliminary heating at $300^{\circ} \mathrm{C}$ for $3 \mathrm{~min}$, the temperature was raised up to $600^{\circ} \mathrm{C}$ at a rate of $25^{\circ} \mathrm{C} / \mathrm{min}$, with a temperature program similar to classical Rock-Eval pyrolysis. Effluents were swept away and condensed, along with the carrier gas, in a trap cooled with liquid nitrogen. After pyrolysis completion, the pyrolysate was recovered by addition of solvent in the trap at room temperature, resulting in argon elimination and loss of $\mathrm{C}_{1}-\mathrm{C}_{5}$ products.

Two pyrolysis experiments were needed for the quantification of the $\mathrm{C}_{6}{ }^{+}$fraction. The first pyrolysate was recovered with $n$-pentane and fractionated by liquid chromatography into saturates and aromatics (Behar et al., 1989). The recovered solutions were injected as such into a gas chromatograph for their quantification by the FID, previously calibrated with an external standard (saturated $\mathrm{C}_{15}-\mathrm{C}_{25}$ distillation cut). Previous molecular analyses of these fractions have enabled to assign carbon content values to the $\mathrm{C}_{6}-\mathrm{C}_{14}$ saturate and aromatic fractions (Behar et al., 1991, 1997) which are respectively 85 and $91 \mathrm{wt} \%$.

The second pyrolysate was recovered in DCM. After solvent evaporation, the $\mathrm{C}_{14}{ }^{+}$fraction was quantified by weighing and submitted to elemental analysis.

For the estimation of the hydrocarbon gas content of the $S 2$ peak, the gas composition from previous studies (Behar et al., 1997) was assigned for each organic matter type (listed in Table 6). The hydrogen content of the $\mathrm{C}_{2}-\mathrm{C}_{5}$ is an average value (82 wt \%) considering that the carbon content is $80 \mathrm{wt} \%$ in $\mathrm{C}_{2}$ and $83 \mathrm{wt} \%$ in $\mathrm{C}_{5}$.

The organic carbon content of the $S 2$ peak (OC (S2)) is calculated as follows:

$$
\begin{aligned}
\mathrm{OC}(S 2) & =\mathrm{Xa} * 0.75+\mathrm{Xb} * 0.82+\mathrm{Xc} * 0.85 \\
& +\mathrm{Xd} * 0.91+\mathrm{Xe}^{*} \mathrm{Ye}
\end{aligned}
$$

where $\mathrm{Xa}$ and $\mathrm{Xb}$ are respectively the $\mathrm{C}_{1}$ and $\mathrm{C}_{2}-\mathrm{C}_{5}$ proportions indicated in Table $6, \mathrm{Xc}$ and $\mathrm{Xd}$ are respectively the proportions of the $\mathrm{C}_{6}-\mathrm{C}_{14}$ saturates and aromatics quantified by gas chromatography, $\mathrm{Xe}$ is the $\mathrm{C}_{14}{ }^{+}$yield determined by weight and $\mathrm{Ye}$ its carbon content measured by elemental analysis.

\section{TABLE 6}

Proportion (wt \%) of $\mathrm{C}_{1}$ and $\mathrm{C}_{2}-\mathrm{C}_{5}$ gas in the $S 2$ peak for standard immature kerogens (after Behar et al., 1997)

\begin{tabular}{c|c|c}
\hline Kerogen type & $\mathbf{C}_{\mathbf{1}}(\mathbf{w t} \%)$ & $\left.\mathbf{C}_{\mathbf{2}}-\mathbf{C}_{\mathbf{5}} \mathbf{( w t} \%\right)$ \\
\hline Type I & 2 & 8 \\
Type II & 3 & 8 \\
Type III & 16 & 13 \\
\hline
\end{tabular}

\subsection{Verification of the MinC for Bulk Rocks}

Two methods were used for verifying the MinC measured by the Rock-Eval 6: the acidimetry technique and the estimation of the weight loss after carbonate destruction.

\subsubsection{Acidimetry Method}

The mineral carbon labeled $\mathrm{MinC}_{\mathrm{ac}}$ can be determined by acidimetry by submitting the bulk rock to $\mathrm{HCl}$ acid treatment (Bienner et al., 1978). Typically, 50 to $400 \mathrm{mg}$ of rock are added to a solution of $\mathrm{HCl} 2 \mathrm{~N}$ and heated at $80^{\circ} \mathrm{C}$ during $30 \mathrm{~min}$. After cooling to room temperature, a sodium hydroxide solution at $1.33 \mathrm{~N}$ is added up to reach a $\mathrm{pH}$ equal to 7. The quantity of sodium hydroxide added is automatically measured and enables the calculation of the quantity of carbonates that were dissolved in the acidic solution (after $\mathrm{pH}$ variation). After this measurement, the samples are washed, dried and weighed. Theoretically, the weight loss $\mathrm{MinC}_{\mathrm{wt}}$ must correspond to the carbonate content determined by acidimetry. In the present study, we will present a comparison between both measurements.

\subsubsection{Estimation of Weight Loss after Carbonate Destruction}

An amount of 0.25-0.26 g of rock sample is placed in a small crucible made of filtering porcelain. Samples are treated with $\mathrm{HCl}(50 \%)$ at room temperature for $24 \mathrm{~h}$ for total elimination of carbonates. Afterwards, samples are washed with hot distilled water. One hour later, they are washed with cold distilled water at least four times for elimination of chlorides. The samples are then dried in an open hood under bulb light at $80^{\circ} \mathrm{C}$. After total drying, the decarbonated samples are weighed for the calculation of the insoluble residue and carbonate content.

The insoluble residue (IR) corresponds to the fraction of the sample not eliminated by $\mathrm{HCl}$ treatment (i.e. noncarbonate minerals and organic matter). To calculate IR, the following formula is used:

$$
\operatorname{IR}(\%)=\mathrm{MI} / \mathrm{MS} * 100
$$


where MI is the mass of the insoluble residue, and MS is the mass of the rock sample before acid treatment. The carbonate content is given by subtracting IR\% from $100 \%$.

In conclusion, based on all the experimental methods described above the following equations and correlations can be done:

- for bulk rocks:

$$
\begin{aligned}
& \mathrm{TOC}+\mathrm{MinC}=\mathrm{TC} \\
& \mathrm{TOC}=\mathrm{C}_{0} \\
& \mathrm{TOC}=\mathrm{C}_{\text {leco }} \\
& \mathrm{MinC}=\mathrm{MinC}_{0} \\
& \mathrm{MinC}=\mathrm{MinC}_{\mathrm{ac}} \\
& \mathrm{MinC}=\mathrm{MinC}_{\mathrm{wt}} \\
& \operatorname{Tmax}_{\mathrm{RE} 2}=\operatorname{Tmax}_{\mathrm{RE} 6} \\
& S 2_{\mathrm{RE} 2} \leq S 2_{\mathrm{RE} 6} \\
& - \text { for pure organic matter (coals and isolated kerogens): } \\
& \mathrm{TOC}=\mathrm{C}_{k} \\
& \operatorname{Tmax}_{\mathrm{RE} 2}=\operatorname{Tmax}_{\mathrm{RE} 6} \\
& S 2_{\mathrm{RE} 2} \leq S 2_{\mathrm{RE} 6}
\end{aligned}
$$

\section{RESULTS AND DISCUSSION}

\subsection{Rock-Eval 6 Data: Reproducibility}

A subset of 109 samples was analyzed by the Standard and the Turbo Rock-Eval 6 which are available in IFP: for both apparatus, each analysis was carefully checked in terms of surface integration and search of the real minimum of $\mathrm{CO}$ and $\mathrm{CO}_{2}$ curves.

During the two to three months' duration of data acquisition, two reference samples were regularly analyzed. The first one is the well-known 55000 source rock (used as a standard for Rock-Eval analysis) and the second one, labeled 46190, is a Toarcian Shale source rock from the Paris Basin. Sample 46190 has a TOC of $7.5 \mathrm{wt} \%$. These two references enable to calibrate the Rock-Eval 6 for a large carbon range (1-10 wt \%) which covers the values usually encountered by organic geochemistry laboratories. It is worth noting that in the 55000 sample, the $S 1$ value is very low, i.e. $0.1 \mathrm{mg} / \mathrm{g}$ : this

TABLE 7

Data accuracy for source rock and kerogen standards analyzed by Turbo and Standard Rock-Eval 6 apparatus

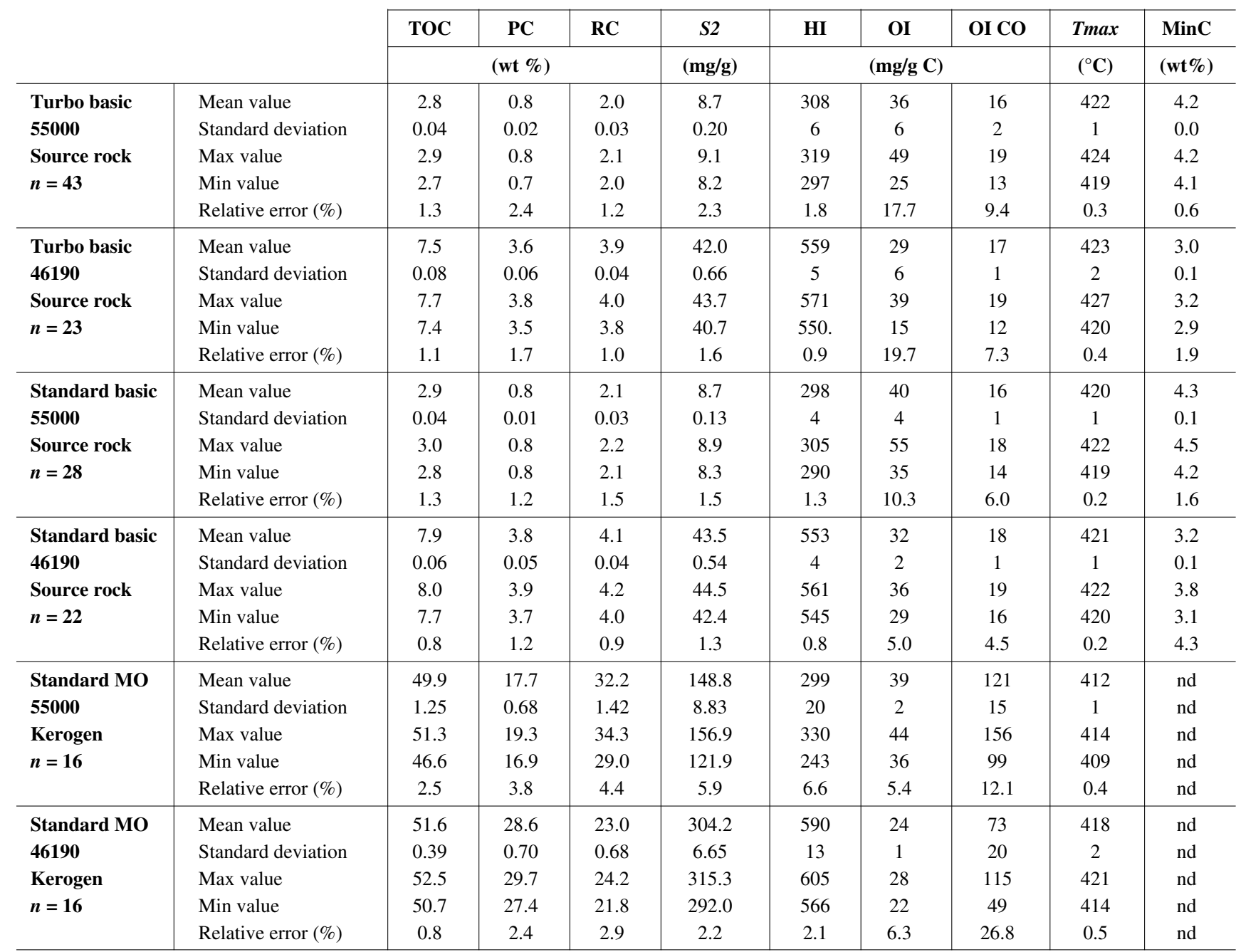


choice was done because samples are usually stored at room temperature in open air. Consequently, the $S 1$ value decreases with time by vaporization of free hydrocarbons and this parameter cannot be reliable on a long duration that is necessary for a standard use.

For both reference samples, organic matter isolation was performed in order to determine the Rock-Eval data accuracy on kerogens. These latter were extracted with DCM, thus the Sl cannot be quantified.

The statistical calculations on reference samples 55000 and 46190 (bulk rocks and kerogens) for Turbo and Standard Rock-Eval 6 available at IFP are reported in Table 7 for parameters listed and defined in Tables $2 \mathrm{a}$ and $2 \mathrm{~b}$.

Basic and pure organic matter methods were used for source rocks and kerogens respectively. For rock data, the TOC is slightly overestimated by the Standard Rock-Eval 6 which leads, as a counterpart, to an underestimation of the HI, since the average $S 2$ values are the same. A less pronounced overestimation is also observed for MinC. $S 2$ measurements show no difference between the two apparatus. Finally, Tmax is slightly lower when measured with the Standard Rock-Eval 6.

In terms of absolute variations, the reproducibility is excellent for TOC, PC, RC, MinC, S2 and HI measured by the two apparatus with less than $2.5 \%$ for the relative error. However, for all parameters except MinC, accuracy is higher for the standard 46190 than for the 55000. This is true for both sets of data measured on source rocks and on isolated kerogens. In contrast, the relative error for MinC, although small, is doubled in comparison to that measured on the 55000 sample. These observations suggest that the data accuracy depends more on the sample itself, i.e. its organic and/or mineral heterogeneity, than on the absolute concentration or value of the parameters measured by Rock-Eval 6 . The total carbon $(\mathrm{TOC}+\mathrm{MinC})$ values measured by the two apparatus were also compared to those obtained by elemental analysis (TC). Data reported in Table 8 show that values obtained with Standard Rock-Eval 6 are closer to TC and thus, data measured with Turbo Rock-Eval 6 are slightly underestimated.

\section{TABLE 8}

Comparison of the total carbon contents for the two standards measured by Rock-Eval 6 and elemental analysis

\begin{tabular}{c|c|c|c}
\hline Source rock & $\begin{array}{c}\text { Turbo } \\
\text { Rock-Eval 6 }\end{array}$ & $\begin{array}{c}\text { Standard } \\
\text { Rock-Eval 6 }\end{array}$ & $\begin{array}{c}\text { Elemental } \\
\text { analysis }\end{array}$ \\
\hline 55000 & $7.0 \pm 0.1$ & $7.2 \pm 0.2$ & $7.3 \pm 0.3$ \\
46190 & $10.5 \pm 0.1$ & $11.1 \pm 0.2$ & $11.5 \pm 0.3$ \\
\hline
\end{tabular}
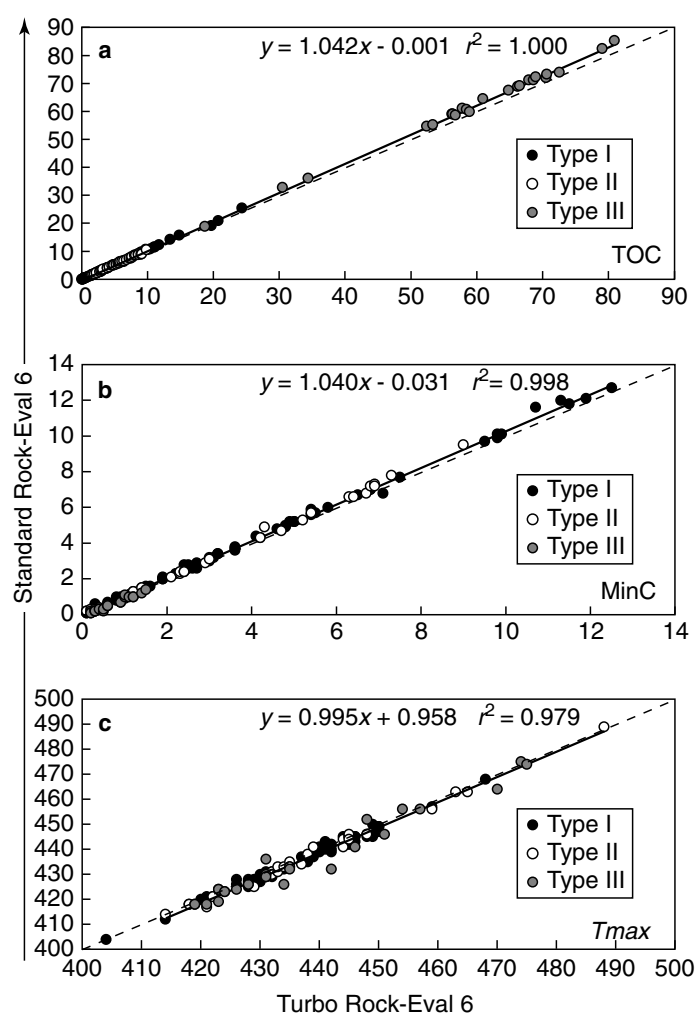

Figure 6

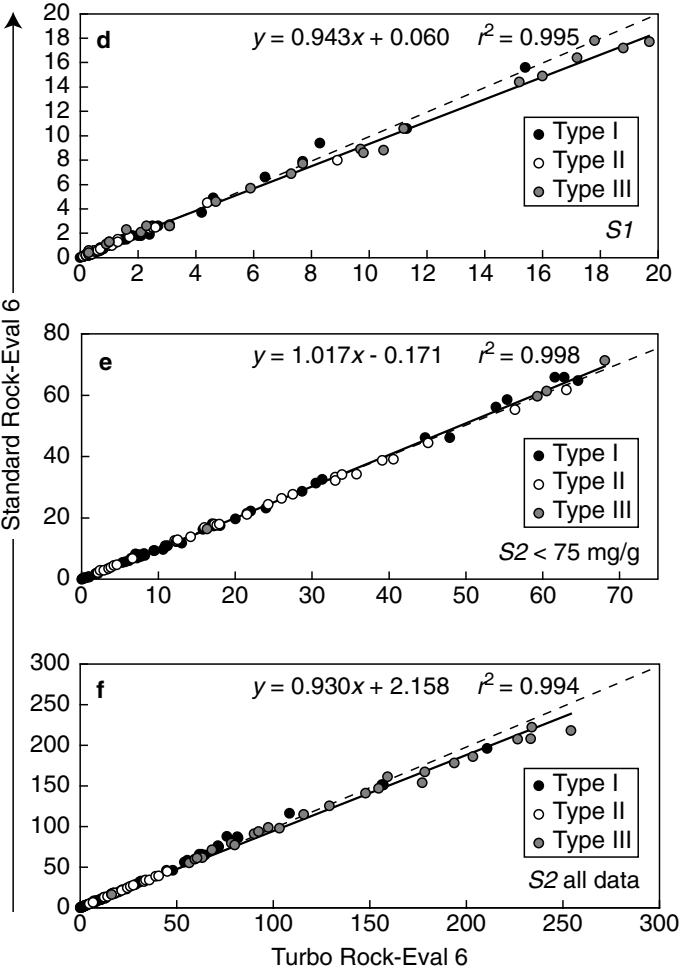

Correlation between Standard Rock-Eval 6 and Turbo Rock-Eval 6 analyses: (a) TOC; (b) MinC; (c) Tmax; (d) $S 1$; (e) $S 2<75 \mathrm{mg} / \mathrm{g}$; (f) $S 2$ all data. 
In order to check the data reproducibility for a large range of variation for each parameter and to check that of the $S 1$, this time, 110 samples among the 147 selected for the present study were analyzed by the two Rock-Eval 6 equipment. Comparisons are given in Figures 6a-6f for TOC (Fig. 6a), MinC (Fig. 6b), Tmax (Fig. 6c), S1 (Fig. 6d) and S2 (Figs. 6e and $6 f)$. For organic and mineral carbon measurements, correlations are excellent for the whole carbon range with an $r^{2}$ higher than 0.998. An excellent agreement between both apparatus is also obtained for Tmax $\left(r^{2}=0.98\right)$. For the $S 1$ and $S 2$ peaks, excellent fits are also observed $\left(r^{2}\right.$ at 0.995 and 0.991 , respectively). A better correlation is observed for $S 2$ values lower than $75 \mathrm{mg} / \mathrm{g}\left(r^{2}=0.998\right)$.

The recorded trend with the two standards (Table 7) of slightly higher TOC and MinC and lower Tmax for Standard Rock-Eval 6 data is also observed for the set of samples.

In conclusion, for the large set of samples investigated, reproducibility for all measured parameters is independent of the organic matter type. These results are very encouraging for inter-laboratory comparison. For the present study, they validate averaging of data from the Standard and Turbo apparatus for comparison with other methods.

\subsection{Verification of the Organic Carbon in the S2 Peak}

The TOC calculated by the Rock-Eval 6 technique is based on the assumption that the carbon content of the $S 2$ is $83 \mathrm{wt} \%$ whatever the organic matter type. This value was established in the past on a Type II sample.

For that purpose, a subset of three series of source rocks representative of the three main organic matter types was selected. Preparative pyrolysis was carried out on kerogens, using the same time/temperature program as that of RockEval 6 (from $300^{\circ}$ to $650^{\circ} \mathrm{C}$ at $25^{\circ} \mathrm{C} / \mathrm{min}$ ).

Table 9 displays consistent results between the $S 2$ measured by Rock-Eval 6 and the total pyrolysate recovered by preparative pyrolysis for Type III kerogens. However, higher yields are systematically obtained by preparative pyrolysis for Type II samples and this is even more pronounced for

TABLE 9

Mass balance $(\mathrm{mg} / \mathrm{g}$ ) obtained by preparative pyrolysis and determination of the carbon content of the total recovered pyrolysate for various kerogens

\begin{tabular}{|c|c|c|c|c|c|c|c|c|c|}
\hline \multirow{2}{*}{ Kerogen type } & \multirow{2}{*}{$\begin{array}{c}S 2 \\
(\mathrm{mg} / \mathrm{g})\end{array}$} & \multirow{2}{*}{$\underset{(\mathrm{mg} / \mathrm{g})}{\mathrm{C}_{1}}$} & \multirow{2}{*}{$\begin{array}{l}\mathrm{C}_{2}-\mathrm{C}_{5} \\
(\mathrm{mg} / \mathrm{g})\end{array}$} & \multicolumn{2}{|c|}{$\mathrm{C}_{6}-\mathrm{C}_{14}(\mathrm{mg} / \mathrm{g})$} & \multicolumn{2}{|l|}{$\mathrm{C}_{14}^{+}$} & \multicolumn{2}{|c|}{ Total pyrolysate } \\
\hline & & & & sat & aro & Total (mg/g) & $\mathrm{C}(\%)$ & Total (mg/g) & $\mathrm{C}(\%)$ \\
\hline I & 605 & 12 & 48 & 67 & 21 & 597 & 85.2 & 745 & 85.0 \\
\hline I & 588 & 12 & 47 & 81 & 18 & 563 & 84.1 & 721 & 83.7 \\
\hline I & 539 & 11 & 43 & 68 & 17 & 493 & 84.9 & 632 & 84.7 \\
\hline I & 459 & 9 & 37 & 57 & 13 & 441 & 84.8 & 558 & 83.8 \\
\hline I & 383 & 8 & 31 & 67 & 13 & 275 & 84.9 & 393 & 84.7 \\
\hline I & 302 & 6 & 24 & 39 & 8 & 203 & 84.5 & 280 & 84.3 \\
\hline I & 180 & 4 & 14 & 31 & 8 & 144 & 82.9 & 201 & 83.3 \\
\hline Average & & & & & & & & & 84.2 \\
\hline II & 331 & 14 & 21 & 21 & 16 & 277 & 79.6 & 349 & 80.4 \\
\hline II & 242 & 18 & 26 & 31 & 15 & 180 & 84.4 & 270 & 84.0 \\
\hline II & 142 & 17 & 21 & 26 & 8 & 92 & 85.1 & 164 & 83.9 \\
\hline II & 304 & 12 & 31 & 21 & 12 & 283 & 79.2 & 359 & 80.0 \\
\hline Average & & & & & & & & & 82.1 \\
\hline III & 193 & 31 & 25 & 14 & 9 & 119 & 83.9 & 198 & 82.6 \\
\hline III & 128 & 20 & 17 & 6 & 6 & 73 & 84.4 & 122 & 82.9 \\
\hline III & 164 & 26 & 21 & 9 & 9 & 91 & 84.7 & 156 & 83.1 \\
\hline III & 138 & 22 & 18 & 8 & 9 & 95 & 80.9 & 153 & 81.0 \\
\hline III & 194 & 31 & 25 & 10 & 10 & 124 & 84.2 & 200 & 82.9 \\
\hline III & 150 & 24 & 20 & 9 & 9 & 101 & 80.8 & 163 & 80.9 \\
\hline III & 217 & 35 & 28 & 17 & 10 & 164 & 82.2 & 255 & 81.8 \\
\hline III & 162 & 26 & 21 & 8 & 7 & 110 & 81.6 & 172 & 81.2 \\
\hline III & 209 & 33 & 27 & 14 & 10 & 138 & 82.9 & 222 & 82.1 \\
\hline III & 185 & 30 & 24 & 12 & 10 & 108 & 83.2 & 183 & 83.8 \\
\hline III & 122 & 20 & 16 & 7 & 6 & 77 & 85.8 & 126 & 82.2 \\
\hline Average & & & & & & & & & 82.9 \\
\hline
\end{tabular}


Type I samples. The observed difference may be due to a slight underestimation of the $S 2$ peak measured on kerogens by Rock-Eval 6: this point is discussed further.

For all samples, whatever the organic matter type, the total $\mathrm{C}_{6}{ }^{+}$pyrolysate represents by far the major fraction of the total pyrolysate with more than $70 \mathrm{wt} \%$. Thus, as the yield and the carbon content of that fraction were determined experimentally for each sample, the carbon content of the total pyrolysate can be accurately determined. The average values found for the three series of kerogens are very similar: $84.2 \mathrm{wt} \%$ for Type I, 82.1 and $82.2 \mathrm{wt} \%$ for Types II and III samples. The average carbon content is $82.8 \mathrm{wt} \%$ which is similar to that proposed by Espitalié et al. (1985a, 1985b, 1985c). This study confirms the validity of the coefficient $83 \mathrm{wt} \%$ used for TOC calculation.

\subsection{Rock-Eval 6 Data: Comparison with Other Methods}

\subsubsection{Total Carbon in Source Rocks}

A total number of 89 samples among the 147 selected were submitted to elemental analyses for a direct measurement of the TC. The comparison between the TC (i.e. TOC $+\mathrm{MinC}$ ) measured by Rock-Eval 6 and elemental analyses is given in Figure 7a for all samples and in Figure 7b for TC values lower than $15 \mathrm{wt} \%$. The correlation obtained with all samples is excellent and matches the $1 \times 1$ correlation for the total

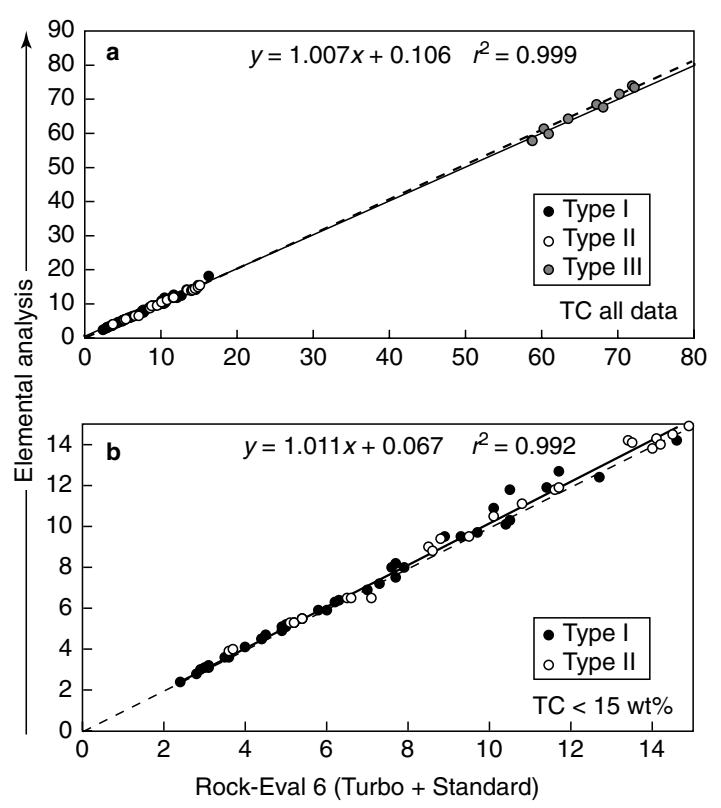

Figure 7

Correlation between Rock-Eval 6 (average values between Standard Rock-Eval 6 and Turbo Rock-Eval 6) obtained on source rocks for: (a) TC and TC determined by elemental analysis for all data; (b) TC and TC determined by elemental analysis for data below $15 \mathrm{wt} \%$. carbon concentration from 2 to $75 \mathrm{wt} \%$. For lower concentrations, the correlation is still very good but the $r^{2}$ is slightly lower, with a value of 0.992 instead of 0.999 . Consequently, absolute quantification of the total carbon by Rock-Eval can be done with a very good accuracy for a very large concentration range.

\subsubsection{TOC in Source Rocks}

As explained in Section 2, the TOC measured on bulk rocks by the Rock-Eval 6 was compared to $\mathrm{C}_{0}$ calculated by mass balance after mineral matrix destruction and elemental analyses of the recovered i.o.m. and TOC measured by the Leco method $\left(\mathrm{C}_{\text {leco }}\right)$.

Figure 8a displays the comparison of Rock-Eval 6 TOC and $\mathrm{C}_{0}$ for all samples, TOC values lower than $15 \mathrm{wt} \%$ are displayed in Figure 8b. For all samples, the correlation is almost perfect since it matches the $1 \times 1$ correlation with an
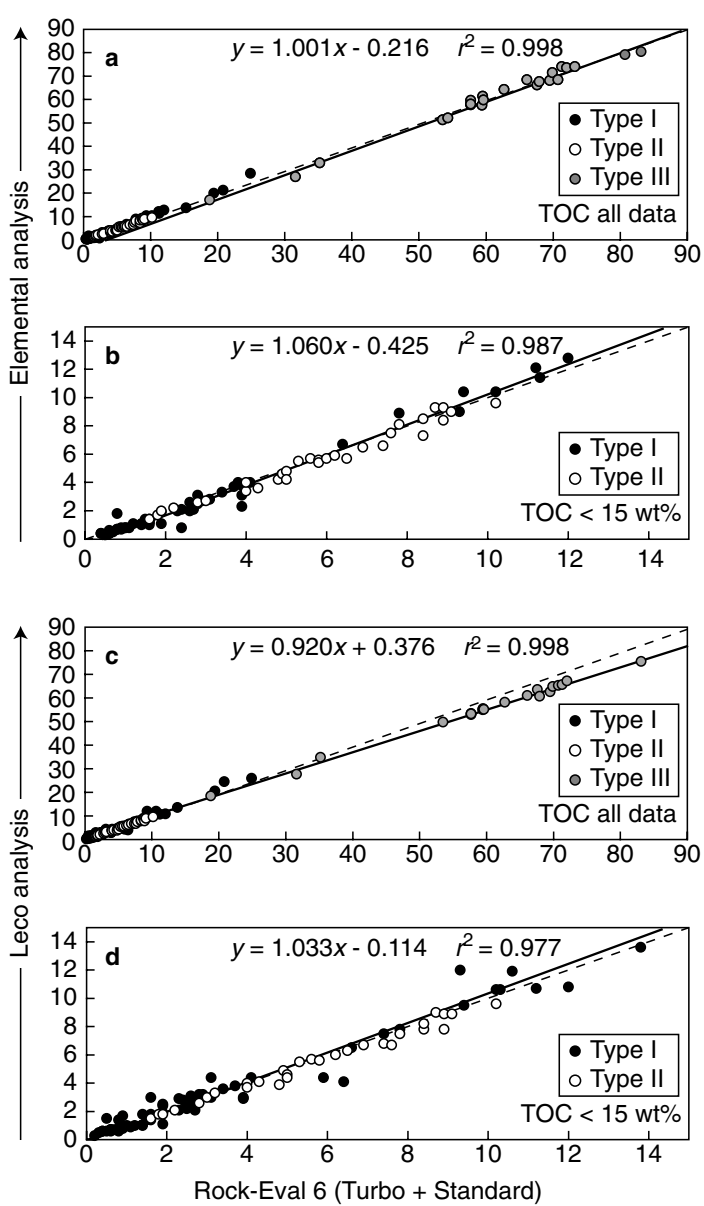

Figure 8

Correlation between Rock-Eval 6 (average values between Standard Rock-Eval 6 and Turbo Rock-Eval 6) obtained on source rocks for: (a) TOC and calculated $\mathrm{C}_{0}$ for all data; (b) TOC and calculated $\mathrm{C}_{0}$ for values lower than $15 \mathrm{wt} \%$; (c) TOC and Leco data for all samples; (d) TOC and Leco data for values lower than $15 \mathrm{wt} \%$. 
$r^{2}$ at 0.998 . For low carbon concentration, the correlation is still excellent even if a slight underestimation is observed for Rock-Eval 6 data. Consequently, the good match of the Rock-Eval data with $\mathrm{C}_{0}$ validates the absolute quantification of the TOC for a very large organic carbon concentration range, i.e. from 0.1 to $80 \mathrm{wt} \%$. It is worth noting that the correlation is still good for very high organic carbon concentration when measured on coals.

A comparison is done with TOC determined by Leco, a very nice correlation $\left(r^{2}=0.998\right)$ is obtained but with a larger deviation from the $1 \times 1$ correlation for TOC above $20 \%$ (Fig. 8c). For samples with TOC lower than $15 \mathrm{wt} \%$ (Fig. 8d), data are more scattered than in the comparison with elemental data. In fact, the Leco measurement is expected to be less precise than $\mathrm{C}_{0}$ because prior to this analysis carbonates have to be removed: during this step, a part of the organic carbon may be hydrolyzed and lost in the aqueous phase and floating organic particles may be lost when washing the sample for eliminating the salts formed during decarbonation (especially for coals).

In conclusion, because of the need of a decarbonation step prior to Leco measurement, $\mathrm{C}_{0}$ data are more precise than those obtained by Leco and as a direct consequence RockEval 6 data are also more reliable than Leco ones.

\subsubsection{Mineral Carbon in Source Rocks}

Prior running bulk rocks containing carbonates, the MinC was quantified on decarbonated rocks. Results, shown in Figure 9, clearly indicate that MinC values do not exceed $0.2 \mathrm{wt} \%$ on carbonate-free rocks. Nevertheless, this value even low does not mean that some residual carbonates are still present after acidic attack because no $S 5$ signal was recorded. This $0.2 \mathrm{wt} \%$ value corresponds to the $S 3$ ' signal, which was assigned to MinC contribution in the Basic Method.

Since the TC determined by elemental analysis represents the sum of the organic and mineral carbon, it is possible to get a calculated value for the mineral carbon $\mathrm{MinC}_{0}$ by

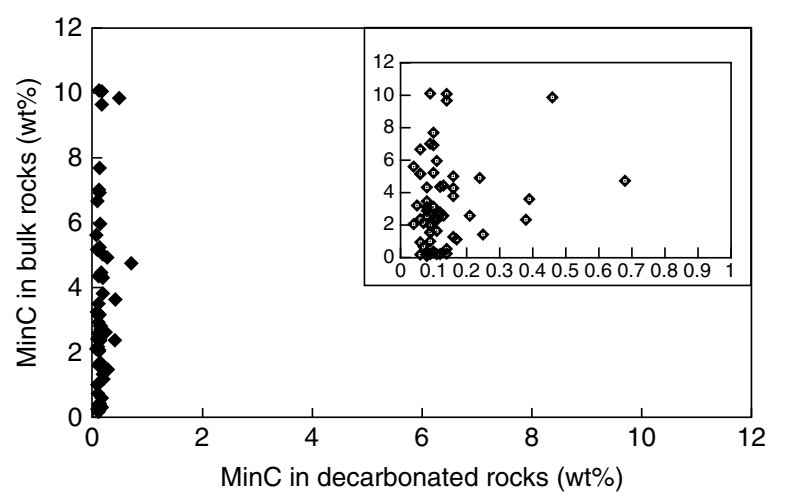

Figure 9

MinC values obtained by Rock-Eval 6 on decarbonated rocks. subtracting the $\mathrm{C}_{0}$ value from TC. $\mathrm{MinC}_{0}$ can be directly compared to MinC determined by Rock-Eval 6 as shown in Figure 10a. A good correlation with $r^{2}=0.983$ is obtained: however, an underestimation is observed with Rock-Eval 6 which seems more pronounced for carbon concentration lower than $4 \%$.

When the same comparison is done with the acidimetry method as indicated in Figure 10b, the $r^{2}$ factor drops from 0.983 to 0.933 and an overestimation with Rock-Eval 6 is observed for values higher than $4 \mathrm{wt} \%$. The measurement of carbonate concentration by the acidimetry method can be erroneous as non-carbonate minerals can be dissolved by $\mathrm{HCl}$ and mistaken for carbonates. Moreover, in an IFP internal report published by Bienner et al. (1978), the authors clearly indicated that this method is less precise that the $\mathrm{CO}_{2}$ volumetric estimation.

Finally, the correlation between MinC measured by RockEval 6 and that estimated by the weight loss during decarbonation is very poor as indicated in Figure 10c.
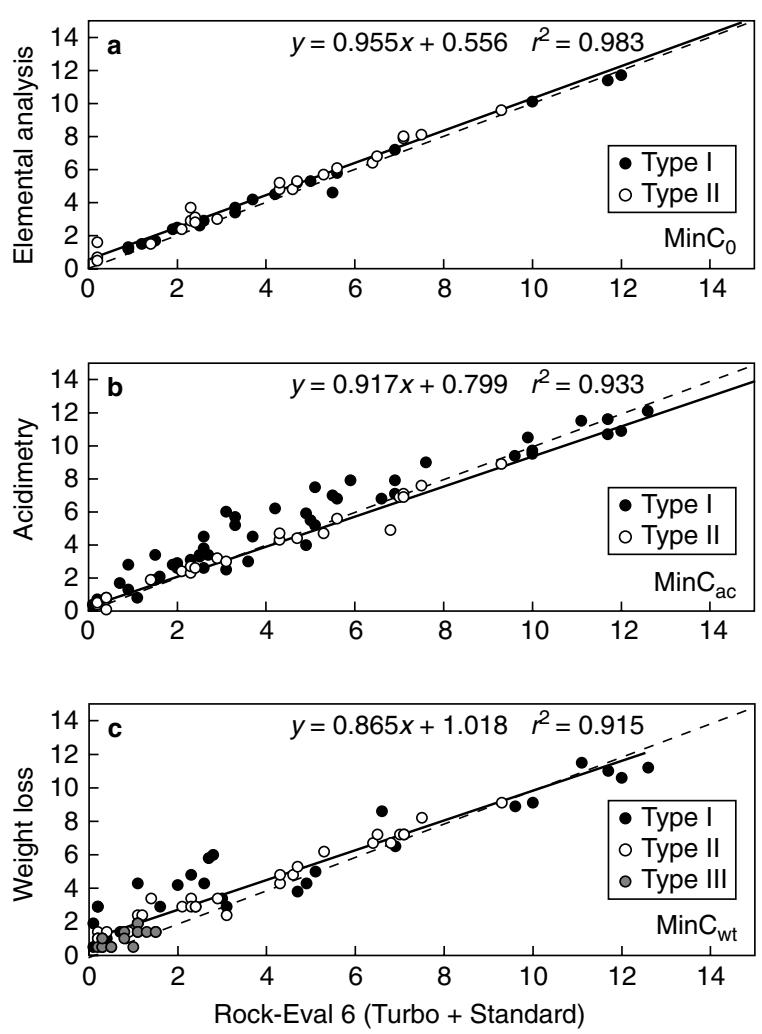

Figure 10

Correlation between Rock-Eval 6 (average values between Standard Rock-Eval 6 and Turbo Rock-Eval 6) obtained on source rocks for: (a) MinC and (TC $-\mathrm{C}_{0}$ ) determined by elemental analysis for all data; (b) MinC and MinC determined by acidimetry; (c) MinC and the weight loss during decarbonation. 


\subsubsection{TOC on Isolated Kerogens}

On a large subset of source rocks (86 samples), kerogen was prepared and then submitted to Rock-Eval 6 pyrolysis and elemental analyses $\left(\mathrm{C}_{k}\right)$. For Type III samples, both coals and clays were submitted to acidic treatment in order to recover the corresponding kerogens. The correlation of the TOC measured by the two methods (Fig. 11) presents an $r^{2}$ of 0.958 and matches the $1 \times 1$ straight line, but data are more scattered than those given in Figure $8 \mathrm{~b}$ for bulk rocks. We have observed that in contrast to bulk rocks and coals, elemental analyses data obtained on isolated kerogens were less precise. This can be explained by the presence of pyrite in most Types I and II samples, which is concentrated in the organic matter recovered after mineral destruction. In that case, since the sample aliquot amount for elemental analyses is lower than $0.5 \mathrm{mg}$ for the $\mathrm{C}, \mathrm{H}$ and $\mathrm{N}$ measurements, whereas the sample aliquot amount is from 1 to $5 \mathrm{mg}$ for Rock-Eval, these aliquots may contain different proportions of pyrite, thus causing the observed deviation.

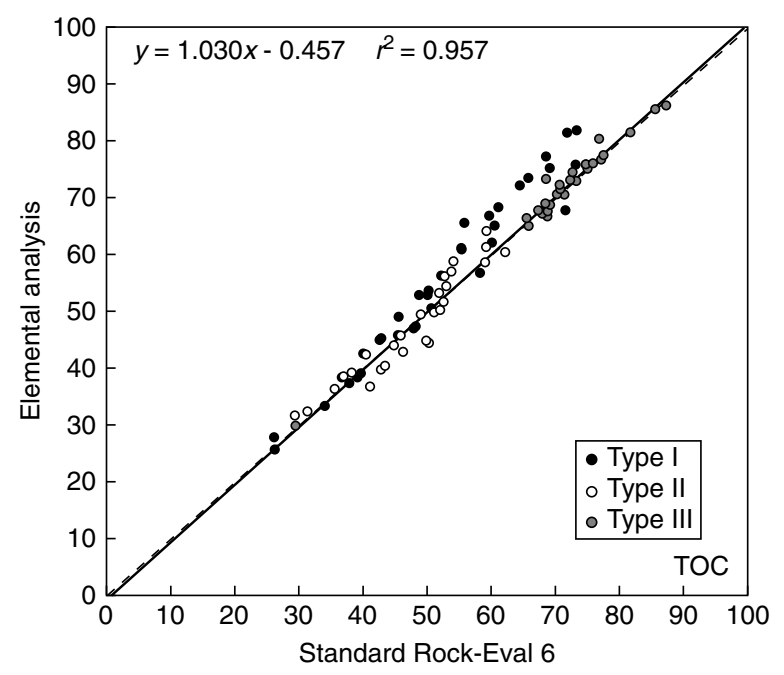

Figure 11

TOC correlation measured on isolated kerogens by Standard Rock-Eval 6 and elemental analysis.

A systematic underestimation by Rock-Eval 6 is observed for Type I kerogens with TOC higher than $50 \mathrm{wt} \%$. However, the difference between the two methods never exceeds $10 \mathrm{wt} \%$. It is worth noting that this difference was not observed for Type III samples when comparing the TC values determined on the initial coals (Fig. 7a) nor when comparing the TOC determined on the isolated kerogen from coals (Fig. 11). The value proposed at $83 \mathrm{wt} \%$ for the carbon content of the $S 2$ peak is slightly lower than that found as the average value for Type I series (Table 7). By applying the specific value of $84.3 \mathrm{wt} \%$ proposed in Table 7 for Type I samples, the TOC values given by the Rock-Eval 6 increase only by near $1 \mathrm{wt} \%$. We have also checked that the FID was not saturated for these kerogens by decreasing the initial sample amount. Similar $S 2$ signals were obtained for different sample amounts (Table 10).

TABLE 10

Influence of the sample amounts on the FID response for a subset of Type I kerogens

\begin{tabular}{l|c|c|c|c|c}
\hline Kerogen & $\begin{array}{c}\mathbf{C}_{k} \\
(\boldsymbol{\%})\end{array}$ & $\begin{array}{c}\text { Weight } \\
(\mathbf{m g})\end{array}$ & $\begin{array}{c}\boldsymbol{S 2} \\
(\mathbf{m g} / \mathbf{g})\end{array}$ & $\begin{array}{c}\text { TOC } \\
(\boldsymbol{\%})\end{array}$ & $\begin{array}{c}\mathbf{R C} \\
(\boldsymbol{\%})\end{array}$ \\
\hline Green River Shale & 81.4 & 5.16 & 609 & 70.3 & 18.1 \\
& & 2.77 & 623 & 71.2 & 18.2 \\
& & 1.89 & 621 & 71.0 & 17.2 \\
\hline Green River Shale & \multirow{2}{*}{81.8} & 5.42 & 625 & 71.1 & 18.4 \\
& & 2.71 & 647 & 73.3 & 17.8 \\
& & 1.31 & 630 & 71.6 & 17.8 \\
\hline Green River Shale & \multirow{2}{*}{60.9} & 5.26 & 469 & 53.2 & 13.5 \\
& & 2.89 & 474 & 53.2 & 12.9 \\
& & 1.56 & 466 & 52.6 & 12.5 \\
\hline
\end{tabular}

When comparing the total pyrolysate recovered by preparative pyrolysis ( $S 2$ from $S 2$ analyzer, reported from Table 9) and the $S 2$ measured with Rock-Eval 6 for Type I kerogens (Table 11), discrepancies increasing with $S 2$ values are observed between the two methods for samples with $S 2$ values higher than $400 \mathrm{mg} / \mathrm{g}$. TOC (labeled b) calculated in substituting the Rock-Eval $6 S 2$ values by the $S 2$ values calculated after preparative pyrolysis results ( $S 2$ from $S 2$ analyzer) leads to values adequate with TOC measured by elemental analysis (labeled a) (Table 11).

This suggests that hydrocarbon effluents produced during pyrolysis of Type I kerogen samples do not undergo a complete combustion in the flame of the FID in the standard conditions $\left(\mathrm{H}_{2} 30 \mathrm{ml} / \mathrm{min}\right.$; air $\left.270 \mathrm{ml} / \mathrm{min}\right)$ defined for routine analysis. In order to test this hypothesis we have measured the $S 2$ value of the sample labeled 7 with different flame conditions by changing the $\mathrm{H}_{2}$ flow. Based on ten measurements for each $\mathrm{H}_{2}$ flow tested, Figure 12 displays that $S 2$ yields can be increased by slight variations of flame conditions. For a $\mathrm{H}_{2}$ flow of $28 \mathrm{ml} / \mathrm{min}$, an average $S 2$ value of $667 \mathrm{mg} / \mathrm{g}$ was obtained, the corresponding calculated TOC is $77.8 \mathrm{wt} \%$. A precise adjustment of flame conditions such as a complete combustion is achieved was not attained. Figure 12 also shows that even though higher yields are obtained with non-standard flame conditions data are more dispersed. Fluctuations of the answers with the $\mathrm{H}_{2}$ flow are not explained. It is worthy to note that analyses of standard 55000 with the different flame conditions tested in this study were leading to constant $S 2$ yields.

As a consequence, Rock-Eval 6 analysis of very rare kerogen samples with $S 2$ values higher than $400 \mathrm{mg} / \mathrm{g}$ is not reliable. TOC values measured for those samples have to be 
TABLE 11

Comparison of TOC measured on Type I kerogens by: a) elemental analysis;

b) Conjugation of $\mathrm{S} 2$ analyzer data for total pyrolysate (given in Table 9) and $\mathrm{CO}$ and $\mathrm{CO}_{2}$ effluents measured by infrared with Rock-Eval 6 (PC from IR and RC); c) Rock-Eval 6

\begin{tabular}{|c|c|c|c|c|c|c|c|c|c|c|}
\hline \multirow{2}{*}{$\begin{array}{c}\text { Sample } \\
\text { label }\end{array}$} & \multicolumn{2}{|c|}{$S 2(\mathrm{mg} / \mathrm{g})$} & \multirow{2}{*}{$\begin{array}{c}\Delta S 2(\mathrm{mg} / \mathrm{g}) \\
\mathrm{S} 2 \text { analyzer } \\
\text { vs. Rock- } \\
\text { Eval } 6\end{array}$} & \multicolumn{2}{|c|}{$\begin{array}{c}\text { PC } \\
(w t \% \text { from } H C)\end{array}$} & \multirow{2}{*}{$\begin{array}{c}\text { PC } \\
\text { (wt \% from IR) } \\
\text { Rock- } \\
\text { Eval 6 }\end{array}$} & \multirow{2}{*}{$\begin{array}{c}\begin{array}{c}\text { RC } \\
(w t \%)\end{array} \\
\text { Rock- } \\
\text { Eval } 6\end{array}$} & \multicolumn{3}{|c|}{$\begin{array}{c}\text { TOC } \\
(w t \%)\end{array}$} \\
\hline & $\begin{array}{c}\text { S2 } \\
\text { analyzer }\end{array}$ & $\begin{array}{l}\text { Rock- } \\
\text { Eval } 6\end{array}$ & & $\begin{array}{c}\text { S2 } \\
\text { analyzer }\end{array}$ & $\begin{array}{l}\text { Rock- } \\
\text { Eval } 6\end{array}$ & & & $\begin{array}{c}\text { (a) } \\
\text { Elemental } \\
\text { analysis }\end{array}$ & $\begin{array}{c}\text { (b) } \\
\text { S2 } \\
\text { analyzer }\end{array}$ & $\begin{array}{c}\text { (c) } \\
\text { Rock- } \\
\text { Eval } 6\end{array}$ \\
\hline 1 & 119 & 115 & 4 & 9.9 & 9.6 & 2.1 & 35.7 & 46.7 & 47.6 & 47.4 \\
\hline 2 & 201 & 179 & 22 & 16.7 & 14.9 & 0.9 & 20.3 & 38.2 & 37.9 & 36.1 \\
\hline 3 & 280 & 302 & -22 & 23.2 & 25.3 & 1.3 & 47.9 & 76.0 & 72.4 & 74.4 \\
\hline 4 & 393 & 383 & 10 & 32.6 & 31.8 & 1.8 & 38.9 & 75.7 & 73.3 & 72.5 \\
\hline 5 & 558 & 463 & 95 & 46.3 & 38.5 & 3.3 & 12.6 & 60.9 & 62.2 & 54.4 \\
\hline 6 & 632 & 538 & 94 & 52.5 & 44.8 & 1.9 & 25.1 & 78.4 & 79.5 & 71.8 \\
\hline 7 & 721 & 584 & 137 & 59.8 & 48.5 & 3.2 & 19.2 & 81.4 & 82.2 & 70.9 \\
\hline 8 & 745 & 614 & 131 & 61.8 & 51.1 & 2.0 & 19.2 & 81.8 & 83.0 & 72.3 \\
\hline
\end{tabular}

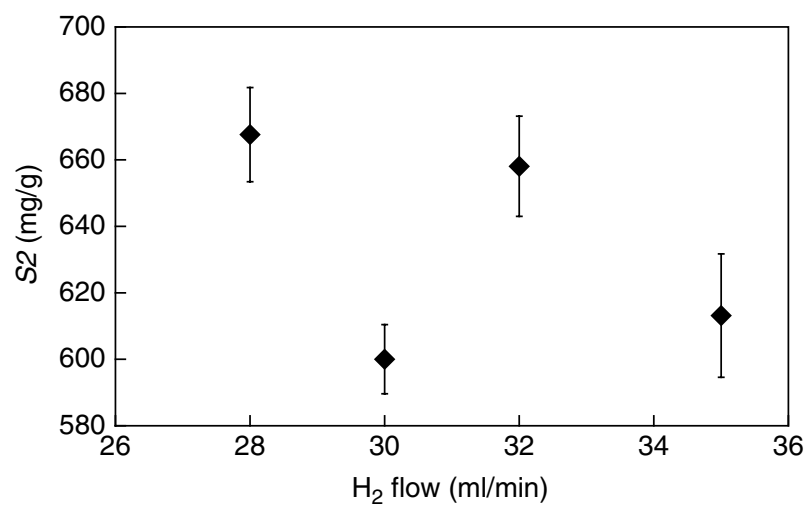

Figure 12

$S 2$ yields for a Type I kerogen $v s$. FID flame conditions: each symbol displays average value for ten measurements; error bars give the standard deviation.

checked by elemental analysis. In case of discrepancy between TOC obtained by elemental analysis on one hand and Rock-Eval 6 analysis on the other hand, the TOC value determined by Rock-Eval 6 will not be valid.

\subsubsection{Comparison of Rock-Eval 6 and Rock-Eval 2 Data}

As mentioned in Section 2, the comparison of $S 2$ and Tmax from Rock-Eval 6 and Rock-Eval 2 was done for Type I and Type II source rocks: this represents around 70 samples. For the $S 2$ peak, the correlation given in Figure 13a is good, with $S 2$ values systematically higher for the Rock-Eval 2 but the difference with Rock-Eval 6 does not exceed 5 relative wt $\%$ for values higher than $80 \mathrm{mg} / \mathrm{g}$ and 10 relative wt $\%$ for values ranging between 20 and $80 \mathrm{mg} / \mathrm{g}$. For Tmax values, the correlation given in Figure 13b displays a deviation between Rock-Eval 2 and Rock-Eval 6 increasing with

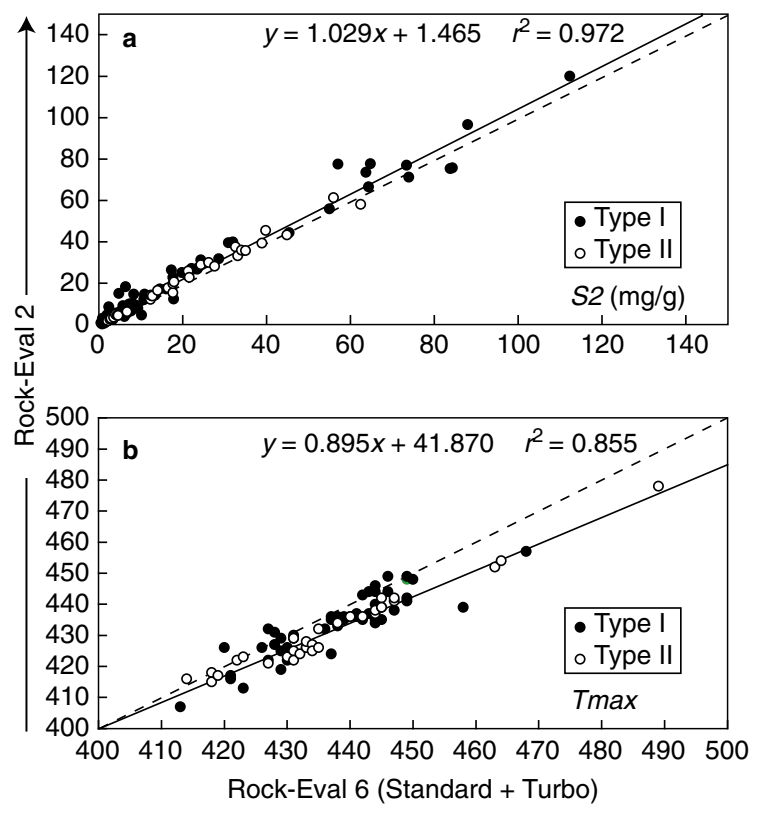

Figure 13

Correlation between Rock-Eval 2 and Rock-Eval 6 data: (a) $S 2(\mathrm{mg} / \mathrm{g})$; (b) Tmax.

Tmax, higher Tmax are recorded with Rock-Eval 6. This fact is intrinsic to the differences between the two Rock-Eval versions, in conditions for temperature measurement described in Section 2.1.4 (probe location), superposed to the carrier gas effect.

Indeed, the differences between these two techniques for estimating $S 2$ are:

- the final pyrolysis temperature $\left(650^{\circ} \mathrm{C}\right.$ for the Rock-Eval 6 and $600^{\circ} \mathrm{C}$ for the Rock-Eval 2);

- the carrier gas (nitrogen and helium respectively). 
A higher pyrolysis temperature is not the right factor for explaining the $S 2$ differences since lower values are measured by Rock-Eval 6.

We have checked the influence of the carrier gas by running reference source rocks (sample 46190) with the Rock-Eval 6 (standard version), using helium or nitrogen. First, we have studied the influence of the sample amount on $S 2$ and Tmax values when pyrolysis is done under helium or nitrogen (Table 12). For sample amounts between 5 and $78 \mathrm{mg}$ the $S 2$ responses are very homogeneous with nitrogen as carrier gas: values are comprised between 42.0 and $44.3 \mathrm{mg} / \mathrm{g}$ (Fig. 14a). In contrast, under helium the $S 2$ response increases from 36.6 to $47.8 \mathrm{mg} / \mathrm{g}$ for the same range of initial amounts (Fig. 14b). For this sample, $S 2$ values obtained under nitrogen on one hand and helium on the other hand are convergent when the product of $S 2$ by amount of sample is around 800. For Tmax, systematically higher values are obtained under nitrogen. As a general trend, Tmax increases with sample size. Displayed data are mean values obtained on three measurements for helium and three to fifteen measurements for nitrogen. Standard deviations obtained for measurements under nitrogen are lower, especially for Tmax values.

In conclusion, more reliable data are obtained under nitrogen: this point is very important for kinetic studies. A comparative kinetic study was also run on reference sample 46190. Data obtained at heating rates ranging from $1^{\circ}$ to $25^{\circ} \mathrm{C} / \mathrm{min}$ are displayed in Table 13 . With helium as carrier gas, it is observed that the $S 2$ yield increases with the heating rate and thus, it is not possible to get consistent data. In contrast, similar values are obtained whatever the heating rates are when using $\mathrm{N}_{2}$ (according to theoretical expectations). Another appreciable consequence of running
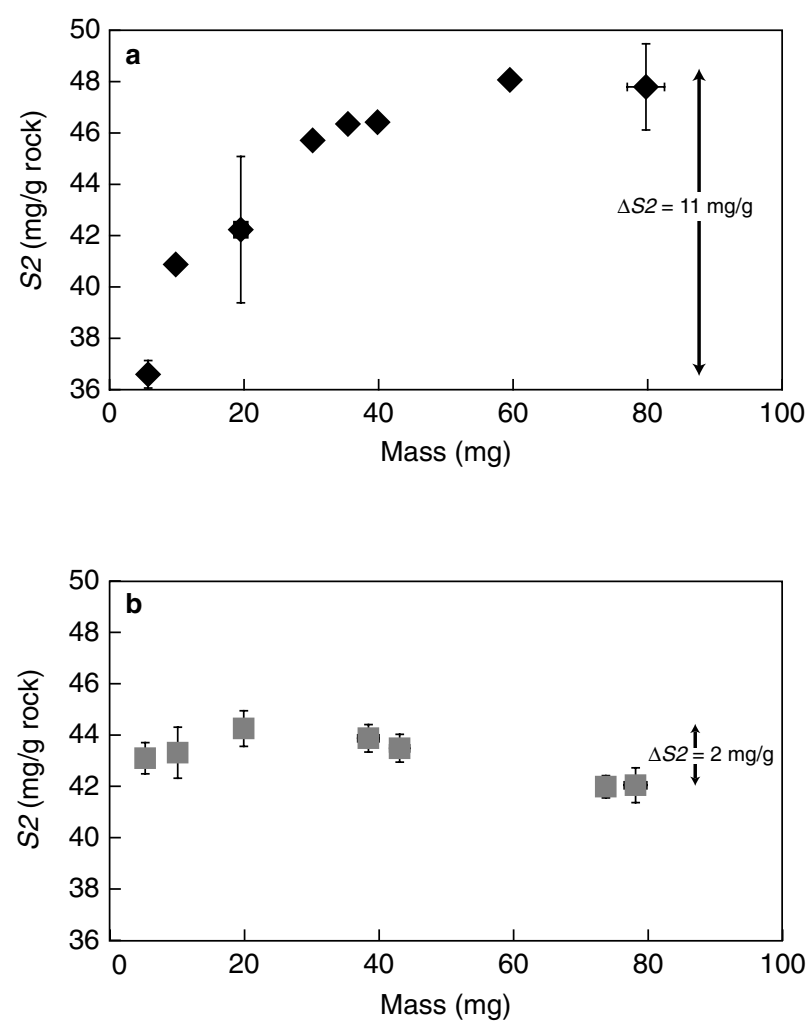

Figure 14

Influence of the carrier gas on the $S 2$ peak measured by Rock-Eval 6: (a) carrier gas = helium; (b) carrier gas = nitrogen.

samples under nitrogen is that the whole system is less sensible to micro gas leaks and thus data are more reproducible.

TABLE 12

Influence of the initial sample amount on the $S 2$ and $\operatorname{Tmax}$ parameters from pyrolysis under nitrogen and helium flow with Rock-Eval 6 on sample 46190

\begin{tabular}{c|c|c|c|c|c|c}
\hline $\begin{array}{c}\text { Sample } \\
\text { amounts (mg) }\end{array}$ & Carrier gas & $\begin{array}{c}\text { S2 } \\
(\mathbf{m g} / \mathbf{g})\end{array}$ & $\begin{array}{c}\text { Standard } \\
\mathbf{d e v i a t i o n}\end{array}$ & $\begin{array}{c}\boldsymbol{T m a x} \\
\left({ }^{\circ} \mathbf{C}\right)\end{array}$ & $\begin{array}{c}\text { Standard } \\
\text { deviation }\end{array}$ & $\begin{array}{c}\boldsymbol{S} \mathbf{2} \times \\
\text { amount }\end{array}$ \\
\hline 5.30 & Nitrogen & 43.1 & 0.6 & 415 & 0 & 228 \\
5.80 & Helium & 36.6 & 0.5 & 411 & 2 & 212 \\
\hline 10.13 & Nitrogen & 43.3 & 1 & 417 & 0 & 439 \\
10.03 & Helium & 40.6 & 0.2 & 413 & 0 & 407 \\
\hline 19.93 & Nitrogen & 44.3 & 0.7 & 419 & 1 & 883 \\
19.59 & Helium & 42.2 & 2.9 & 415 & 2 & 827 \\
\hline 38.48 & Nitrogen & 43.9 & 0.5 & 421 & 1 & 1689 \\
35.50 & Helium & 46.4 & 0.1 & 414 & 2 & 1647 \\
\hline 43.13 & Nitrogen & 43.5 & 0.6 & 421 & 1 & 1876 \\
39.90 & Helium & 46.4 & 0.3 & 415 & 1 & 1851 \\
\hline 73.78 & Nitrogen & 42.0 & 0.4 & 423 & 1 & 3099 \\
79.81 & Helium & 47.8 & 1.7 & 418 & 4 & 3815 \\
\hline
\end{tabular}


TABLE 13

Estimation of the $S 2$ peak by Rock-Eval 6 under helium and nitrogen for various heating rates

\begin{tabular}{c|c|c}
\cline { 2 - 3 } \multicolumn{1}{c|}{} & \multicolumn{2}{|c}{$\mathbf{4 6 1 9 0}$ source rock } \\
\hline${ }^{\circ} \mathbf{C} / \mathbf{m i n}$ & $\boldsymbol{S 2} \mathbf{( H e )}$ & $\boldsymbol{S 2}\left(\mathbf{N}_{\mathbf{2}}\right)$ \\
\hline 25 & 47.0 & 42.7 \\
15 & 44.2 & 43.0 \\
10 & 43.6 & 42.1 \\
5 & 41.0 & 43.0 \\
2 & 38.4 & 42.3 \\
1 & 35.3 & 42.1 \\
\hline
\end{tabular}

Whatever, the correlations observed in Figures 13a and $13 \mathrm{~b}$ for both $S 2$ and Tmax values do not preclude comparison of data obtained by Rock-Eval 2 and those obtained by RockEval 6 for confident geochemical interpretation.

\section{CONCLUSION}

The new version of the Rock-Eval technique, i.e. the RockEval 6, was commercialized for the first time in 1996. Its main new technology was focused on a better measurement of temperature along the heating program, and a specific measurement of carbon oxide effluents which enables discrimination between mineral and organic carbon. The aim of our study was to determine the accuracy of the different parameters determined by the Rock-Eval 6 and to crosscheck the quality of quantitative values by other independent techniques.

In terms of reproducibility, two standards were analyzed regularly during two to three months on both Rock-Eval 6 equipment available in our laboratory: the first one is the Turbo version and the second one a Standard version. The relative error for $S 2$, TOC, HI, PC, RC, MinC and Tmax was found to be lower than $2.5 \mathrm{wt} \%$ for both apparatus. $S 1$ was not analyzed because of its very low content in our standards. The relative error is higher for OI and OI CO and a specific study is in progress for improving the measurement of these two parameters.

After checking of the data reproducibility, 147 bulk rocks, including two series of coals, were selected from the IFP rock collection. All the analyses were duplicated on our two apparatus. The comparison of the whole set of Rock-Eval parameters, including the $S 1$, from both apparatus demonstrates a very good intra-laboratory reproducibility.

For checking the absolute carbon measurement by RockEval 6, the TC of almost 100 bulk rocks, including the two series of coals, was determined by elemental analyses. The correlation between the two methods was found excellent and almost fits the $1 \times 1$ straight line all along the investigated carbon range from $2 \mathrm{wt} \%$ to values higher than $80 \mathrm{wt} \%$. This means that the Rock-Eval 6 technique is as accurate as the elemental analysis for measurement of the total carbon on a very large concentration range.

For the specific determination of the total organic carbon (TOC), results obtained with Rock-Eval 6 were compared to $\mathrm{C}_{0}$ which is a calculated value based on the yield of organic matter recovered after mineral destruction and on the carbon content of this organic matter. It was shown that $\mathrm{C}_{0}$ is a very reliable parameter because its estimation is given with a relative error of $1.6 \mathrm{wt} \%$. The quality of the correlation between TOC and $\mathrm{C}_{0}$ from less than 0.5 to more than $80 \mathrm{wt} \%$ demonstrates the reliability of TOC measurements with Rock-Eval 6. Comparison with Leco data $\left(\mathrm{C}_{\text {leco }}\right)$ was not as spectacular because the analytical protocol for Leco analysis includes an acidic attack followed by several water washings that may lead to loss of organic material.

Knowing the TC and $\mathrm{C}_{0}$, the mineral carbon $\mathrm{MinC}_{0}$ is obtained by difference. $\mathrm{MinC}_{0}$ was compared to MinC determined by Rock-Eval 6. Although the correlation displays an $r^{2}=0.983$, there is a slight underestimation by Rock-Eval 6 but it is not significant enough to shift the TC value estimated by this technique compared to that obtained by elemental analysis. In contrast, a poor correlation is obtained when comparing the Rock-Eval $6 \mathrm{MinC}$ and the value obtained by acidimetry method $\left(\mathrm{MinC}_{\mathrm{ac}}\right)$ which cannot be considered as a reliable technique for calibrating this parameter.

For organic carbon measurement on pure organic matter, i.e. isolated kerogens, the correlation between Rock-Eval data and elemental analysis is still excellent for kerogens from Types II and III organic matter. However an underestimation between 5 and 10 relative wt $\%$ of Rock-Eval 6 results to elemental analysis is observed for Type I immature samples.

In conclusion, for total, organic and mineral carbon determination on source rocks and coals, Rock-Eval 6 is a powerful technique. Very accurate data can be obtained at once for complete ranges for both organic and mineral carbon: 0 to $90 \mathrm{wt} \%$ and 0 to $12 \mathrm{wt} \%$ respectively within one hour. We recommend to select three or four samples on which TC, $\mathrm{C}_{0}$ and MinC are known as standards for checking these parameters at least once a week. Therefore, following this methodology, it is no more necessary to calibrate these parameters by other methods, which means a significant reduction in the experimentation time.

Finally, it was demonstrated that for Types I and II source rocks, $S 2$ and Tmax measured by Rock-Eval 2 and RockEval 6 are fully consistent. However, a slight underestimation of the $S 2$ is observed for Rock-Eval 2. This effect is linked to the change of carrier gas from helium to nitrogen in RockEval 6 which is justified by acquisition of more robust data.

The Tmax correlation is characterized by scattered data due to the position of the probe in the Rock-Eval 2, which implies less accuracy compared to Rock-Eval 6. A special attention was given for temperature measurement on RockEval 6 leading to much more reliable data. 


\section{ACKNOWLEDGEMENTS}

Special thanks are expressed to T. Lesage, F. Le Bihan, R. Martinez, C. Leblond and B. Jarry for all the analyses undertaken at IFP. T. Lesage is also acknowledged for drawing the figures of the present paper. D. Pillot and F. Marquis are acknowledged for their devotedness in developing the Rock-Eval 6.

We would also like to express our gratitude to Dr. Luiz Antonio Freitas Trindade, head of the Geochemistry Section at the Petrobras $R \& D$ Center, for authorization and encouragement in running Rock-Eval 2 analyses for this study. Special thanks are due to Ligia Jeremias Lemos de Aquino and Marcelo Santos Lima, laboratory technicians responsible for the Rock-Eval 2 analyses undertaken in the geochemical laboratories in Rio de Janeiro, Brazil.

\section{REFERENCES}

Behar, F. and Pelet, R. (1985) Pyrolysis-Gas Chromatography Applied to Organic Geochemistry, Structural Similarities Between Kerogens and Asphaltenes from Related Rock Extracts and Oils. J. Anal. Appl. Pyr., 8, 173-187.

Behar, F., Saint-Paul, C. and Leblond, C. (1989) Analyse quantitative des effluents de pyrolyse en milieu ouvert et fermé. Rev. Inst. fr. Pét., 44, 3, 387-397.
Behar, F., Ungerer, P., Kressmann, S. and Rudkiewicz, J.L. (1991) Thermal Evolution of Crude Oils in Sedimentary Basins: Experimental Simulation in a Confined System and Kinetic Modelling. Rev. Inst. fr. Pét., 46, 2, 151-181.

Behar, F., Vandenbroucke, M., Tang, Y., Marquis, F. and Espitalié, J. (1997) Thermal Cracking of Kerogen in Open and Closed Systems: Determination of Kinetic Parameters and Stoichiometric Coefficients for Oil and Gas Generation. Org. Geochem., 26, 5/6, 321-339.

Bienner, F., Laporte, J.L. and Espitalié, M. (1978) Méthodes de dosage dans les roches du carbone minéral et organique mises au point et pratiquées dans la Division Géologie IFP. IFP report, No. 22330.

Durand, B. and Nicaise, G. (1980) Procedure for Kerogen Isolation, Kerogen, Durand, B. (ed.), Éditions Technip, 35-53.

Espitalié, J., Deroo, G. and Marquis, F. (1985a) La pyrolyse Rock-Eval et ses applications. Oil \& Gas Science and Technology, 40, 5, 563-579.

Espitalié, J., Deroo, G. and Marquis, F. (1985b) La pyrolyse Rock-Eval et ses applications. Oil \& Gas Science and Technology, 40, 6, 755-783.

Espitalié, J., Deroo, G. and Marquis, F. (1985c) La pyrolyse Rock-Eval et ses applications. Oil \& Gas Science and Technology, 41, 1, 73-89.

Lafargue, E., Marquis, F. and Pillot, D. (1998) Rock-Eval 6 Applications in Hydrocarbon Exploration, Production and Soils Contamination Studies. Oil \& Gas Science and Technology, 53, 4, 421-437.

Final manuscript received in February 2001 